NBER WORKING PAPER SERIES

\title{
THE DISTRIBUTION OF COVID-19 RELATED RISKS
}

\author{
Patrick Baylis \\ Pierre-Loup Beauregard \\ Marie Connolly \\ Nicole Fortin \\ David A. Green \\ Pablo Gutierrez Cubillos \\ Sam Gyetvay \\ Catherine Haeck \\ Timea Laura Molnar \\ Gaëlle Simard-Duplain \\ Henry E. Siu \\ Maria teNyenhuis \\ Casey Warman \\ Working Paper 27881 \\ http://www.nber.org/papers/w27881 \\ NATIONAL BUREAU OF ECONOMIC RESEARCH \\ 1050 Massachusetts Avenue \\ Cambridge, MA 02138 \\ October 2020
}

We are extremely grateful to the dedicated set of people at Statistics Canada who made this work possible: Marc St. Denis, Cindy Cook, Andrew Heisz, Kelly Cranswick, Monica Pereira, Bin Hu, Adam Howe, Gabrielle Beaudoin, Jacques Fanteux, Lynn Barr-Telford, and Anil Arora. We are particularly grateful to Reka Gustafson at the BC Centre for Disease Control for her insight and advice, and to Tony Bonen and the Labour Market Information Council for support. We wish to thank CIRANO for financial support. Molnar thanks Analysis Group for supporting her pro bono involvement in a previous stage of this collaboration. The views expressed herein are those of the authors and do not necessarily reflect the views of the National Bureau of Economic Research or the Bank of Canada.

NBER working papers are circulated for discussion and comment purposes. They have not been peer-reviewed or been subject to the review by the NBER Board of Directors that accompanies official NBER publications.

(C) 2020 by Patrick Baylis, Pierre-Loup Beauregard, Marie Connolly, Nicole Fortin, David A. Green, Pablo Gutierrez Cubillos, Sam Gyetvay, Catherine Haeck, Timea Laura Molnar, Gaëlle Simard-Duplain, Henry E. Siu, Maria teNyenhuis, and Casey Warman. All rights reserved. Short sections of text, not to exceed two paragraphs, may be quoted without explicit permission provided that full credit, including $(\odot)$ notice, is given to the source. 
The Distribution of COVID-19 Related Risks

Patrick Baylis, Pierre-Loup Beauregard, Marie Connolly, Nicole Fortin, David A. Green, Pablo Gutierrez Cubillos, Sam Gyetvay, Catherine Haeck, Timea Laura Molnar, Gaëlle Simard-Duplain, Henry E. Siu, Maria teNyenhuis, and Casey Warman

NBER Working Paper No. 27881

October 2020

JEL No. E32,I18,J15,J16,J21

\section{ABSTRACT}

This paper documents two COVID-related risks, viral risk and employment risk, and their distributions across the Canadian population. The measurement of viral risk is based on the VSE COVID Risk/Reward Assessment Tool, created to assist policymakers in determining the impacts of economic shutdowns and re-openings over the course of the pandemic. We document that women are more concentrated in high viral risk occupations and that this is the source of their greater employment loss over the course of the pandemic so far. They were also less likely to maintain one form of contact with their former employers, reducing employment recovery rates. Low educated workers face the same virus risk rates as high educated workers but much higher employment losses. Based on a rough counterfactual exercise, this is largely accounted for by their lower likelihood of switching to working from home which, in turn, is related to living conditions such as living in crowded dwellings. For both women and the low educated, existing inequities in their occupational distributions and living situations have resulted in them bearing a disproportionate amount of the risk emerging from the pandemic. Assortative matching in couples has tended to exacerbate risk inequities.

Patrick Baylis

Vancouver School of Economics

University of British Columbia

6000 Iona Drive

Vancouver, BC V6T1L4

Canada

pbaylis@mail.ubc.ca

Pierre-Loup Beauregard

Vancouver School of Economics

University of British Columbia

6000 Iona Drive

Vancouver, BC V6T1L4

Canada

pierreloup.beauregard@gmail.com

Marie Connolly

Université du Québec à Montréal

C.P. 8888, Succ. Centre-ville

Montréal QC H3C 3P8

Canada

connolly.marie@uqam.ca
Nicole Fortin

Vancouver School of Economics

University of British Columbia

\#997-1873 East Mall Vancouver,

BC V6T, 1Z1 and NBER

nicole.fortin@ubc.ca

David A. Green Vancouver

School of Economics University

of British Columbia 6000 Iona

Drive Vancouver, BC V6T1L4

Canada

green@econ.ubc.ca

Pablo Gutierrez Cubillos

Vancouver School of Economics

University of British Columbia

6000 Iona Drive Vancouver, BC

V6T1L4

Canada

pgutiecu@mail.ubc.ca 
Sam Gyetvay

Vancouver School of Economics

University of British Columbia

6000 Iona Drive

Vancouver, BC V6T1L4

Canada

sam.gyetvay@gmail.com

Catherine Haeck

Université du Québec à Montréal

C.P. 8888, Succ. Centre-ville

Montréal QC H3C 3P8

Canada

haeck.catherine@uqam.ca

Timea Laura Molnar

Central European University

Department of Economics and Business

Quellenstrasse 51

Vienna, 1100

Austria

molnartl@ceu.edu

Gaëlle Simard-Duplain

Centre for Innovative Data

in Economics Research

Vancouver School of Economics

University of British Columbia

6000 Iona Drive

Vancouver, BC V6T 1L4

Canada

simardduplain@gmail.com

Henry E. Siu

Vancouver School of Economics

University of British Columbia

6000 Iona Drive

Vancouver, BC V6T 1L4

CANADA

and NBER

hankman@mail.ubc.ca
Maria teNyenhuis

Financial Stability Department

Bank of Canada

Ottawa, ON, Canada K1A 0G9

mtenyenhuis@bankofcanada.ca

Casey Warman

Department of Economics

Dalhousie University

6214 University Avenue,

Room A23

Halifax, NS B3H 4R2

CANADA

and NBER

warmanc@dal.ca

VSE COVID Risk/Reward Assessment Tool

https://covid19.economics.ubc.ca/projects/project-1/

Github repository

https://github.com/pbaylis/vse-risk-tool 


\section{Introduction}

Risk is a pervasive element of the labour market. Workers face both exposure to illness and injury while at work, and income risks associated with variation in wages, hours and job loss. Those risks are not equally distributed. It is well known, for example, that less educated workers have greater variability in employment across the business cycle. And lower income workers may be compelled to go to work even when they are sick or when there is illness at their place of work because of their precarious income position - a point of interaction of the two types of risk. The COVID pandemic introduced substantially heightened risks of both types: it represents a new health risk that can be transmitted in close work arrangements and it required the shut-down of whole industries, with associated job losses. Our goal in this paper is to characterize these two types of work-related COVID risks with a focus on understanding how the risks vary across different groups of workers defined by gender, immigrant status, age, and education. That is, we want to understand who is bearing the risks from COVID and how the health and job loss risks interact.

Workers can vary in their exposure to risks but the ultimate impact of that exposure depends on their ability to adjust to mitigate the risk. For COVID related health risks, one key way to adjust is to switch to working at home, where the worker is not exposed to risk of sickness from co-workers. For job loss risk, labour hoarding by firms will reduce the risk for some workers. For others, they may be placed on some form of temporary lay-off or put on an extended sick leave with or without pay. To the extent these adjustments are without pay, these forms of adjustment are less about helping workers with income loss during the firm downsizing than potentially allowing them to move more quickly back into work when the economy begins to recover. A third form of adjustment may come within households. If members of a household work in different industries with different levels of virus risk and job loss risk then the household can do some amount of self-insuring, smoothing the income related risks to some degree. Access to these forms of adjustment is likely unequally distributed which would imply that differential exposures to the initial risks could be exacerbated by differential ability to mitigate the risks if they do materialize. Moreover, an inability to adjust to mitigate the effects of job loss (because, for example, of a lack of assets and savings) could lead to workers going to work sick, increasing their health risks and those of their co-workers. Our investigation includes examinations of these various forms of adjustment and how they differ by groups in society. 
Carrying out this investigation requires a measure of the risk of acquiring the virus by workers at different workplaces. We use a measure we created to help in advising the federal and some provincial governments in the early part of the pandemic. In late March, 2020, the Director of the British Columbia Centre for Disease Control (BCCDC), Réka Gustafson, approached the Vancouver School of Economics (VSE) to analyse the economic impacts of the growing pandemic. The VSE formed several teams to examine different aspects of that impact, but a central component was to develop a means to characterize which parts of the economy were likely to be most affected. It is worth noting that at that point, there were no comprehensive surveys that included information on who was getting sick and where they worked. Shortly after starting this work, the VSE team became aware of researchers in Montréal and Halifax who were also working on this issue and a collaboration was undertaken between the two tools. A key part of the work concerned developing a list of characteristics of workers and their jobs that were most likely to put them at risk of contracting the virus. We worked with the BCCDC and its Quebec counterpart, the Institut national de santé publique du Québec (INSPQ), to create that list. The result was an index of riskiness (described in more detail below) that became the central element of the VSE COVID-19 Risk/Reward Assessment Tool. We describe the Tool in Section 2 of the paper.

Several other researchers have developed measures of viral risk exposure. To the best of our knowledge, all other approaches have used only occupational workplace characteristics from the Occupational Information Network ( $\mathrm{O}^{*} \mathrm{NET}$ hereafter) to conduct their analyses. For example, Dingel and Neiman (2020) focus on how likely is it that workers in a given occupation can work from home. They use a set of O*NET "Work Context" conditions (e.g., physical proximity, whether a worker spends the majority of the time on the job walking) and "Work Activities" conditions (e.g., handling and moving objects, and operating vehicles), categorizing jobs as able to be done from home if any of the criteria do not apply. Similarly, a media outlet analysis by the New York Times (Gamio (2020)) and one by the Brookfield Institute (Vu and Malli (2020)) consider the O*NET measures of physical proximity and exposure to disease and infection to rate occupations by COVID risk.

Our approach differs from other investigations in two important ways. First, we used input from public health experts to determine the set of characteristics that were most relevant for viral transmission. Second, our analysis includes characteristics of workers and their circumstances outside of work, not simply occupational characteristics from the O*NET. Part of what we learned from public health experts is that the spread 
of the SARS-CoV-2 virus depends not just on workplace conditions and interactions, but also critically on non-work conditions. ${ }^{1}$ This combination of workplace and worker information is unique. We were able to include worker characteristics because Statistics Canada provided remote access to non-public use Census and Labour Force Survey (LFS) data. We approached Statistics Canada early in our work regarding issues faced in developing useful measures for the BCCDC and the INSPQ based only on public use microdata. Statistics Canada responded with remarkable speed and helpful assistance in working with the data.

The result is an interactive tool that includes our measure of viral transmission risk, the individual job and worker characteristics that underlie that measure, as well as measures of the economic importance of occupations. Our measures are available by 4-digit occupation and 3-digit sector level, at the national and provincial levels.

Access to the administrative Census data allows for further analysis. We are able to investigate who works in high-risk occupations along dimensions such as gender, income/poverty, and immigrant status. Combined with LFS data at the 4 digit occupation level, we examine what groups were most exposed to viral risk and what groups faced the largest job losses during the pandemic, and how these two risks interacted. In Section 3 we describe the distribution of the virus risk, showing that women faced much higher exposure to this risk because of the occupations in which they are concentrated. In Section 4 we examine the risk of job loss providing evidence for the claim that this is a 'she-cession' relative to earlier recession and also showing much larger job losses for the low educated and recent immigrants. We bring the two types of risk together in Section 5, finding that high risk occupations experienced much higher rates of job loss and that extra job loss for women can be entirely explained by their concentration in high virus risk occupations. In contrast, the low educated job loss happens across occupations, regardless of their level of virus risk. We follow up this analysis in Section 6 with an examination of modes of adjustment to these risks. We find that women are further disadvantaged by having forms of work loss that involve lower ongoing connections with the firm. Using a rough counterfactual, we also find that the low educated experienced extra job loss because they were less able to make the switch to working from home. That lower ability to switch, in turn arose because of their living conditions, such as their greater likelihood of living at home. Thus, inequities in living arrangements have made

\footnotetext{
${ }^{1}$ For example, the outbreak of March/April centred on the Alberta meat processing plant was sizeable not just because of the close proximity of workers in an indoor work environment. The viral spread was in large part because the workers tended to live in crowded dwellings, and made more concerning because employees came from a community that included a considerable proportion of health care workers.
} 
themselves felt in job losses. In this and in the concentration of women in virus exposed occupations, the pandemic has revealed and amplified inequities in society. The path forward involves not just income support but paying real attention to gender differences in occupations and to inequalities in living arrangements.

\section{The Risk/Reward Assessment Tool}

The VSE COVID-19 Risk/Reward Assessment Tool (VSE COVID Risk Tool, hereafter) was created to help policymakers assess which occupations and sectors face the greatest risk of SARS-CoV-2 virus transmission. This was done in April of 2020 to provide guidance on the "re-opening" of provincial economies, and aid in the monitoring of economic renormalization. The tool is also potentially useful in determining which sectors should be closed down in any second wave of viral spread.

The VSE COVID Risk Tool allows comparison of the viral transmission risks of occupational-and-sectoral activity relative to its importance to the economy. Our measure of viral transmission risk (the VSE Risk Index, hereafter) - the primary element of importance for this paper - is constructed at the 4-digit 2016 National Occupational Classification (NOC) code level, the finest level available in the Census and LFS. The characteristics we use in the VSE Risk Index (detailed below) were determined in close consultation with public health experts at the BCCDC and INSPQ, as those deemed most likely to expose workers to risk based on what they were seeing in the population. They highlight specific concerns related both to the physical conditions at work and the living conditions for workers outside of the workplace. The analysis is performed separately for each province (except in the case of New Brunswick and Prince Edward Island, which were combined for data disclosure reasons), and for the Canadian economy as a whole. In this section, we provide details on the tool itself, and the construction of the risk index and economic importance measures.

\subsection{The Interactive Tool}

In creating the VSE COVID Risk Tool, we followed three general design principles. First, the tool should be intuitive, so that new users have minimal difficulty comparing the viral transmission risk and economic importance for the set of sectors and occupations that comprise each province's economy. Second, it should make disaggregated data available, allowing users to obtain a wide range of relevant sector, occupation, and household 
Figure 1: VSE COVID Risk Tool: Exhibit 1

Figure: Sectors and major occupation groups

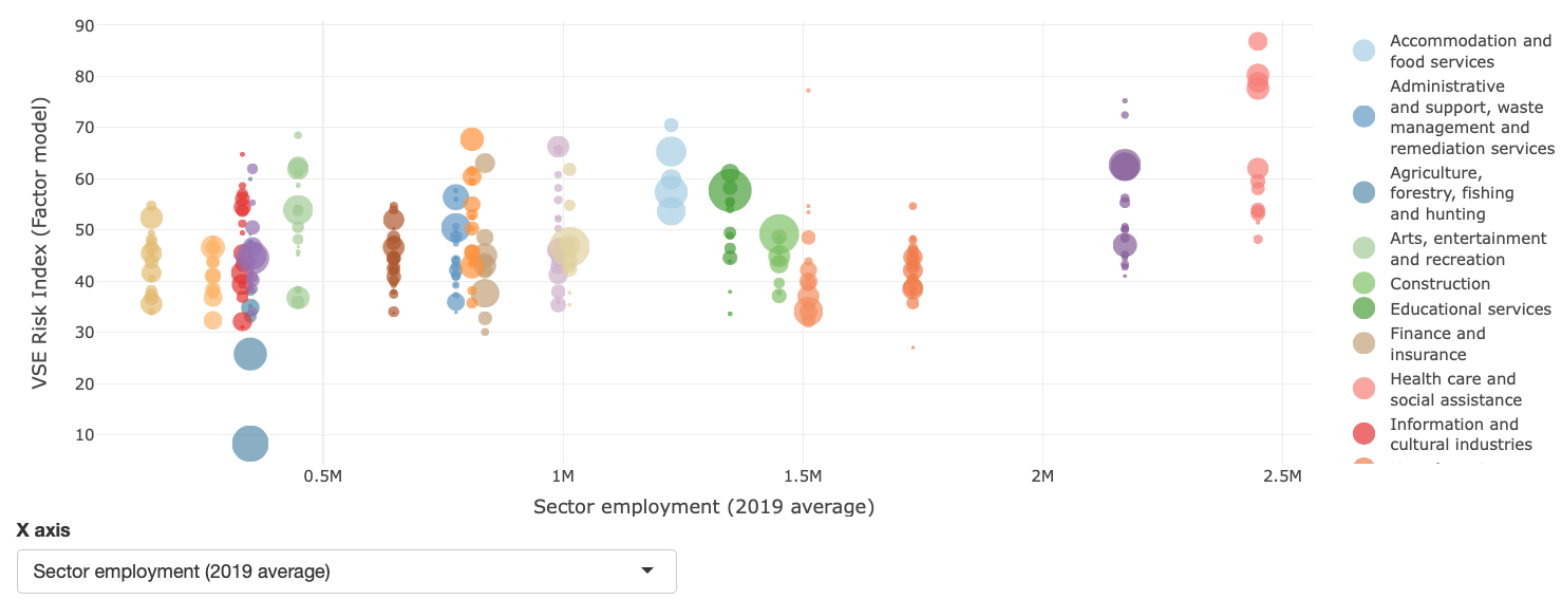

Notes: Web application can be accessed at https://COVID19.economics.ubc.ca/projects/ project-1/.

characteristics. Third, the aggregated and disaggregated views into the data should be linked in a straightforward manner.

To fulfill the principle of being intuitive, the primary figure in the tool (see Figure 1 below) is simply a scatterplot, with one of a set of measures of economic importance of a sector on the horizontal axis and the VSE Risk Index value on the vertical axis. Each point in the plot represents a sector-occupation combination, scaled to indicate the occupation's within-sector labor share. Users select different indicators of economic importance (all given at the 3-digit subsector level), including average sector employment in 2019, change in employment between February and April 2020, change in employment between February and April 2020 for jobs with wages that would place them in the lowest quartile of the wage distribution in 2019, and sectoral share of GDP.

The table that follows the figure in the tool (see Figure 2) fulfills the second principle of making disaggregated data available. Because these data represent the most granular occupation and subsector data available and include a large range of variables, there are thousands of rows and more than thirty columns to be displayed. To overcome this challenge, the tool uses a dynamic table: "pages" limit the number of rows displayed at once, "tabs" group variables by type, and filtering is available for all variables. Figure 2 shows a view of the table filtered to the "Retail trade" (code 44) sector and "Sales representatives and salesperson - wholesale and retail trade" occupation group (code 64). Third and finally, the figure and table are linked together. Users may click points in the 
Figure 2: VSE COVID Risk Tool: Exhibit 2

Table: Subsector and occupation unit groups

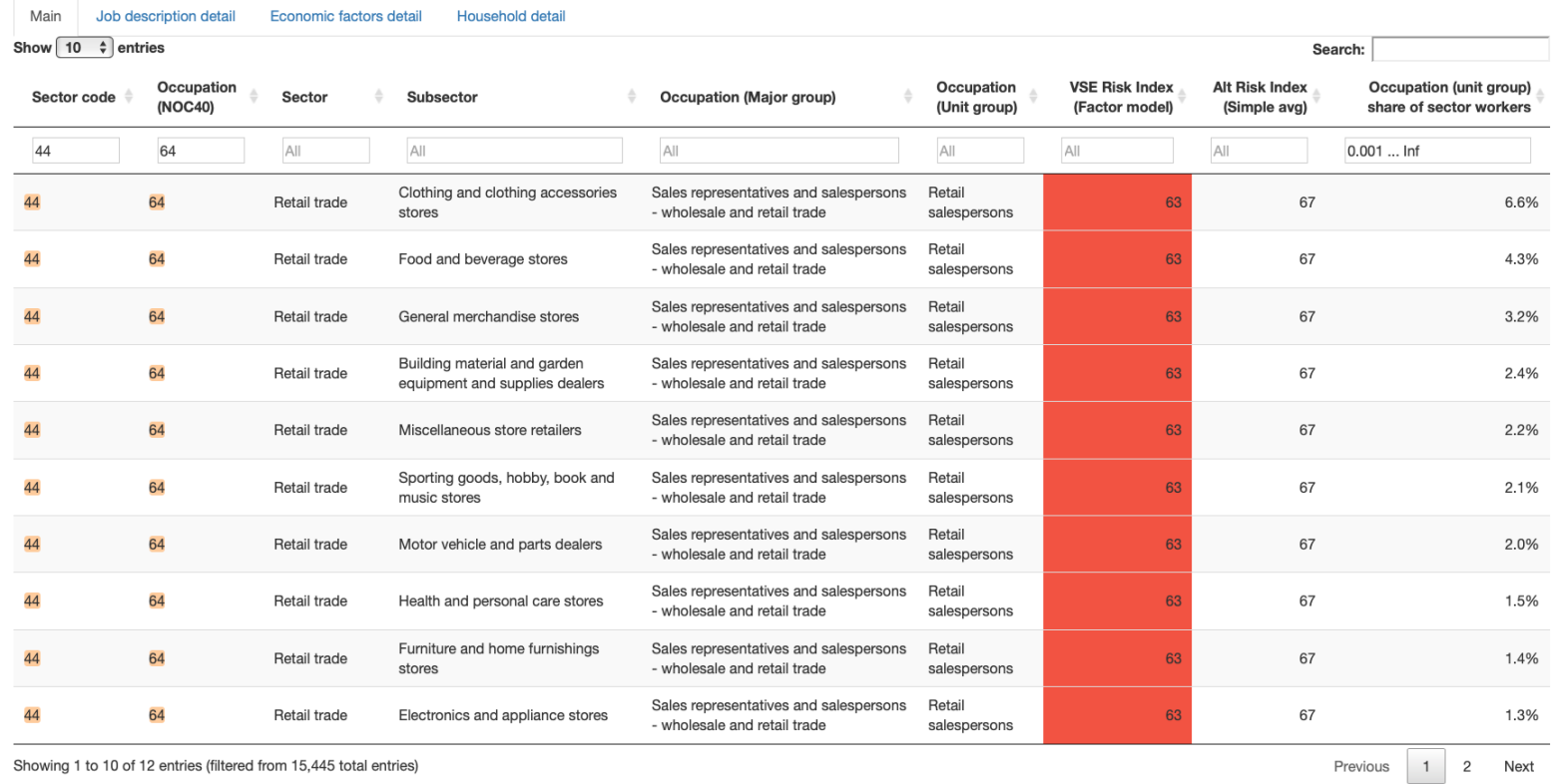

Notes: Web application can be accessed at https://COVID19.economics.ubc.ca/projects/ project-1/.

figure to apply the relevant occupation and sector filters to the table to learn detailed information on all of the disaggregated occupations within the larger occupation group.

The tool is an interactive web application that can be accessed at https://COVID19. economics.ubc.ca/projects/project-1/. All of the code used to build the tool is available on the Github repository https://github.com/pbaylis/vse-risk-tool, where more detail on its construction is available, as well as instructions for running it on a user's own system. ${ }^{2}$

\subsection{Viral Transmission Factors: Job Characteristics}

The VSE Risk Index is constructed using two principal data sources. The first source documents occupational work characteristics from the Occupational Information Network (O*NET) Version 24.2. This is a U.S. based data source that provides information on approximately 300 characteristics of an occupation including skills required in performing

\footnotetext{
${ }^{2}$ Code to generate the tool is written in the statistical programming software R (https://www.rproject.org/), with the help of the interactive development environment RStudio (https://rstudio.com/). Three packages are central to the development of the tool: Shiny (https://shiny.rstudio.com/) provides methods for creating a web app, the figure is generated using plotly (https://plotly.com/r/), and the dynamic table using DT (https://rstudio.github.io/DT/). The tool is hosted using Shinyapps.io (https://www.shinyapps.io/), a (paid) hosting service for Shiny apps.
} 
job tasks and abilities possessed by workers in that occupation.

For our purposes, we focus on the "Occupational Requirements" domain of O*NET, detailing work activities, behaviours, and physical work conditions. Under the "Work Content" and "Work Activities" categories of this domain, individuals employed in an occupation as well as experts on the occupation rate aspects of a job on a scale from 1 to 5 (the response scale is provided below). We use responses for:

- Physical Proximity: To what extent does this job require the worker to perform job tasks in close physical proximity to other people? $[1=$ Don't work near other people (beyond $100 \mathrm{ft}$. ), $2=$ Work with others but not closely (e.g., private office), $3=$ Slightly close (e.g., shared office), $4=$ Moderately close (at arm's length), $5=$ Very close (near touching)],

- Exposed to Disease or Infections: How often does this job require exposure to disease/infections? $[1=$ Never, $2=$ Once a year or more but not every month, $3=$ Once a month or more but not every week, $4=$ Once a week or more but not every day, $5=$ Every day ,

- Outdoors: How often does this job require working outdoors? We use both measures provided in the O*NET, working "Exposed to Weather" and "Under Cover" [Same scale as Exposed to Disease or Infections],

- Contact With Others: How much does this job require the worker to be in contact with others (face-to-face, by telephone, or otherwise) in order to perform it? $[1=$ No contact with others, $2=$ Occasional contact with others, $3=$ Contact with others about half the time, $4=$ Contact with others most of the time, $5=$ Constant contact with others],

- Performing for or Working Directly with the Public: Performing for people or dealing directly with the public. [Importance measure; $1=$ Not important at all, $2=$ Somewhat Important, $3=$ Important, $4=$ Very Important, $5=$ Extremely important].

The $\mathrm{O}^{*}$ NET provides information for 974 occupations coded according to the Standard Occupational Classification (O*NET-SOC) system. We use a crosswalk developed by Marc Frenette at Statistics Canada (Statcan) to map these into the NOC 2016, which has approximately 500 occupation unit groups at the finest 4-digit level of granularity. ${ }^{3}$

\footnotetext{
${ }^{3}$ Whenever multiple O*NET-SOC (origin) occupations map into one NOC (destination) occupation, we take a simple average over the origin occupations' scores.
} 


\subsection{Viral Transmission Factors: Worker Characteristics}

The second important source of information is the 2016 Census of Population, from which we obtained worker characteristics by occupation. Because we wanted to examine those characteristics at the narrowest (4-digit) occupation level, the public use version of the Census was not sufficient for our purposes. Because of pandemic-related closures, the confidential files could not be accessed via Statcan's Regional Data Centres (RDC). We approached Statcan and were given very rapid remote access to the data we required, in walled-off parts of their servers. Statcan adapted RDC protocols so that we could access the confidential data and have our research results vetted to make sure confidentiality requirements were met.

Since SARS-CoV-2 transmission depends importantly on factors outside of the workplace, characteristics of workers obtained from the Census play an important role in our measurement of viral transmission risk. The inclusion of these characteristics is unique to our analysis. The variables listed below correspond to the proportion of workers employed in a 4-digit NOC occupation code that have a certain characteristic:

- Works from Home: job is located in the same building as their place of residence, who live and work on the same farm, or spend most of their work week working at home,

- Public Transit: takes public transit to work, including bus, subway/elevated rail, light rail/streetcar/commuter train and passenger ferry as the main mode of commuting, but excluding carpooling,

- Lives with Health Worker: lives with someone who works in ambulatory health care services, hospitals, or nursing and residential care facilities,

- Crowded Dwelling: lives in an "unsuitable dwelling", where a dwelling is deemed unsuitable if it has too few bedrooms for the size and composition of the household, according to the National Occupancy Standard.

Again, the characteristics listed in Subsections 2.2 and 2.3 were chosen in collaboration with public health officials as those most relevant to viral transmission risk.

\subsection{The VSE Risk Index}

Currently available data does not allow us to directly observe SARS-CoV-2 transmission risk. Hence, a key issue is determining how to aggregate the various occupational and 
worker characteristics listed above into a single risk index. To the extent that these characteristic measures vary together, they capture changes in an underlying or latent risk of transmission. We exploit this intuition in the construction of the VSE Risk Index.

We do so via factor analysis, in which a set of observed variables are portrayed as combinations of an underlying subset of unobserved latent variables called "factors". The coefficients associating factors to each of the observed variables are called "factor loadings". For the VSE Risk Index, we focus on the first factor, which involves finding the combination of measures that accounts for the largest proportion of their covariance. ${ }^{4}$ The first factor represents a common element in the set of characteristics listed above; in that sense, it is a natural candidate for the VSE Risk Index. To facilitate interpretation as an index, we normalize this factor to $[0,100]$ scale.

The factor analysis delivers intuitive results with respect to the ranking of occupations by viral transmission risk. Health-related occupations uniformly occupy the top of the distribution. At greatest risk are Dentists, General practitioners and family physicians, and Respiratory therapists, clinical perfusionists and cardiopulmonary technologists, with VSE Risk Index scores of 100, 94, and 91, respectively. The riskiest non-health occupations are Pursers and flight attendants and Food service supervisors, largely because of their very close physical proximity and constant contact with others. At the other extreme, occupations with the lowest risk scores are Chain saw and skidder operators, Managers in agriculture, and Conductors, composers and arrangers, with VSE Risk Index scores of 0,7 , and 10, respectively. For the sake of brevity, we refer readers to the VSE COVID Risk Tool for details regarding other occupations and associated sector risk measures, at https://COVID19. economics.ubc.ca/projects/project-1/.

\subsection{Economic Importance Variables}

In addition to the VSE Risk Index, the VSE COVID Risk Tool provides several measures of the relative economic importance of specific sectors. These measures are constructed at the 3-digit (or "subsector") categorization level in the North American Industry Classification System (NAICS), Canada 2017 Version 3.0. In terms of importance, sectors can be compared along three dimensions.

The first is simply the size of the sector, in terms of employment or GDP. The second is in terms of sectoral employment losses between February and April 2020, which varied widely across sectors. For instance at the national level, employment was essentially

\footnotetext{
${ }^{4}$ We find that the first factor explains well over $50 \%$ of the total covariance in the observed variables.
} 
halved in Accommodation and Food Services, while Finance and Insurance saw very little change in employment. The tool also allows users to focus on job loss in the bottom quartile of the wage distribution. As is well known, the effects of recessions are disproportionately borne by those most economically disadvantaged; the unprecedented shutdown in this episode is no exception (as discussed below). Finally, sectors can be organized by a measure of network centrality: how essential they are to the functioning of all other sectors of the economy, in terms of intersectoral input-output linkages.

\subsection{Use of the Tool by Policy Makers}

The VSE COVID Risk Tool was created to aid policymakers assess the risks and benefits of re-starting various sectors of the economy or, if needed, re-introduction of closures or restrictions if a second wave emerges. Since the VSE Risk Index is measured at the occupational level, the tool also allows policymakers to identify, within sectors, jobs or areas that require particular attention.

To date, results have been shared in British Columbia with senior officials within the Premier's office, the Ministries of Finance, Health, and Social Policy and Poverty Reduction, the BCCDC, and also WorkSafe BC, the agency responsible for workplace injury and illness that is overseeing safety in the province's Restart Plan. In Quebec, results have been shared with the Ministry of Finance and the INSPQ.

At the federal level, the VSE COVID Risk Tool has been shared with senior officials at Health Canada, Public Health Agency of Canada, Public Safety Canada, the Canadian Centre for Occupational Health and Safety, Statistics Canada, the Bank of Canada, as well as numerous federal ministries. The Labour Market Information Council (LMIC) generously supported our research to extend the analysis beyond BC and Quebec to all provinces and the Canadian economy at the national level. Through the LMIC, the VSE COVID Risk Tool has been shared with its constituent ministries (those principally of labour and skills development) from each province and territory. In addition, the tool has been shared with public health officials from each province and territory.

\section{Who Bears the Risk of Viral Transmission?}

We begin by using the VSE Risk Index and its component series to investigate who is most exposed to workplace viral risk from COVID. We do this at the 4-digit occupational level, asking whether certain demographic and skill groups are disproportionately employed in 
Figure 3: Regression of risk on occupation-level characteristics: all occupations
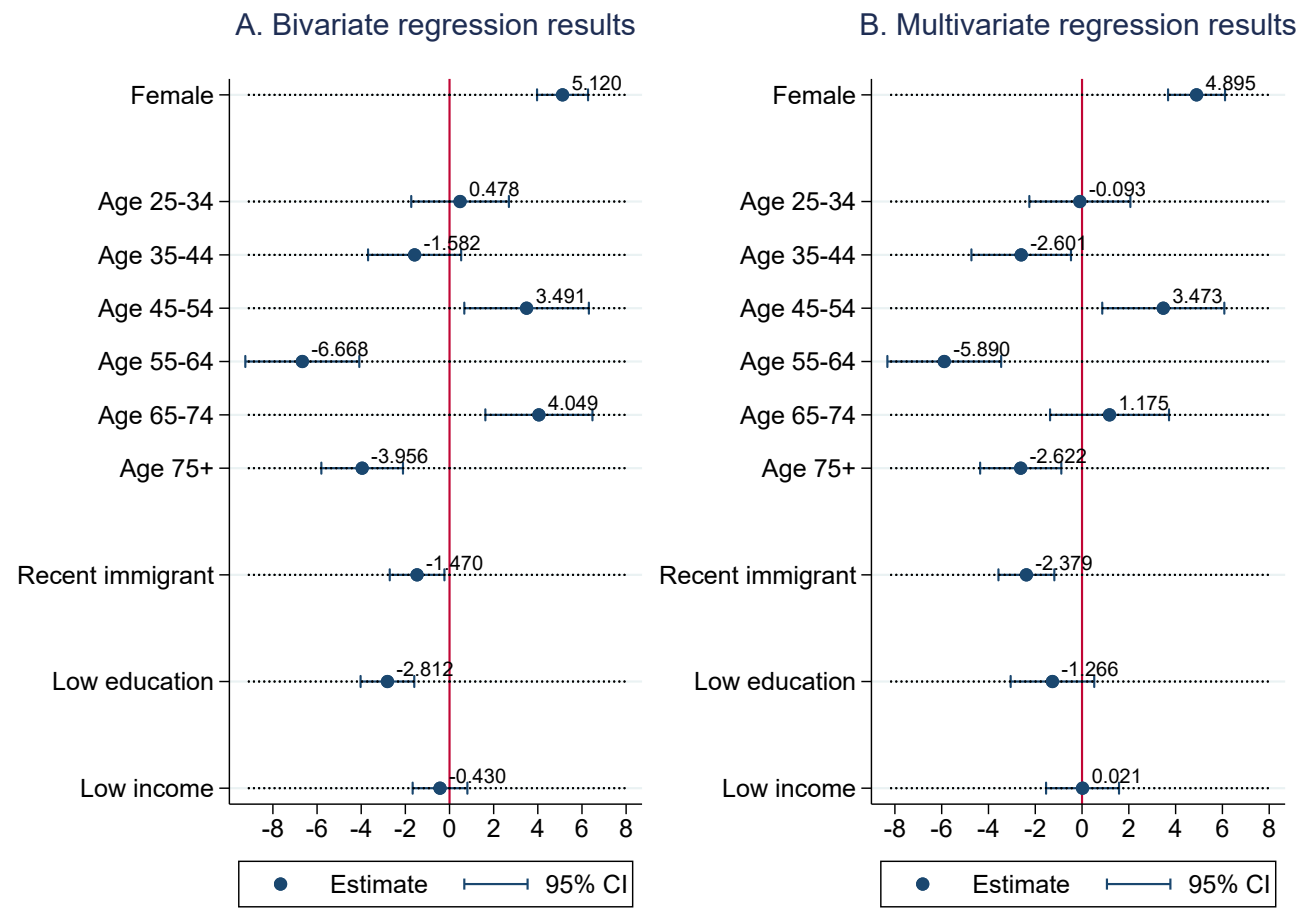

Notes: Point estimates and 95\% confidence intervals of VSE Risk Index regressed on demographic characteristics of 4-digit NOC occupations. Panel A presents bivariate regression results, Panel B presents multivariate results. See text for details.

occupations with high virus risk scores.

In Figure 3, we present results from regressing the VSE Risk Index on the proportion of workers in a given occupation who are: female; belong to different age groups; are recent immigrants (i.e., immigrated to Canada in the previous 10 years); have lower educational attainment (high school or less); and live in low-income households (as defined by the after-tax Market Basket Measure poverty line). These are characteristics that may be associated with risk, but are not included in the construction of the risk index. Results in Figure 3, Panel A come from bivariate regressions, with the exception of the age variables, which are included together in a single regression (with 15-24 year olds as the excluded group). Results in Figure 3, Panel B come from a (multivariate) regression of the VSE Risk Index on the full set of variables.

Our principle finding is that gender is an important correlate of viral transmission risk: a one-standard-deviation increase in the proportion of workers who are female is associated with a 5.12 point increase in the average risk index, or approximately one 
third of a standard deviation. ${ }^{5}$ By comparison, risk is only modestly (and negatively) associated with the prevalence of immigrants across both specifications. Risk displays a negative relationship with low education only in the bivariate case, and is not associated with the proportion of individuals from low-income families. Age bears a non-linear relationship to viral risk, with occupations with a high concentration of workers aged 45 to 54 being relatively high risk and those with more workers in the 55 to 64 year old range being relatively low risk.

In Figure 4, we unpack the patterns in Figure 3 by presenting the relationship between the demographic and skill factors and the different components of the risk index. Each entry in a line shows the marginal effect of the corresponding factor (e.g., proportion of workers who are female) in a multivariate regression of the risk component on the full set of factors. The results are expressed in fractions of a standard deviation of the risk component. Women tend to work in occupations with much greater viral transmission risk with respect to all $\mathrm{O}^{*} \mathrm{NET}$ characteristics compared to men; this is indicated in the left-most figure in the first row of Figure 4 (note that "working outdoors" is associated with lower risk). In addition, while female-dominated jobs feature a lower proportion of workers that cohabitate with a health care worker, they are more associated with all other census-based characteristics included in the VSE Risk Index. Thus, female workers have both home and work characteristics associated with greater virus risk.

By contrast, the weak relationship between immigrant status and overall viral risk shown in Figure 3 is the result of offsetting occupational and worker characteristics. Immigrant-dominated occupations tend to have lower direct contact with others, especially the public (lowering their viral transmission risk), but their workers have a greater tendency to live in crowded dwellings and to take public transit to work (increasing their risk). This is important given recent concerns that racialized populations face greater risk from the virus. Our results indicate that this is not true in terms of workplace arrangements but is true in terms of living conditions.

It is possible that the higher viral risk for females, and the lower risk for immigrants, stems from their respective over- and under-representation in health-related occupations. In Figure 5, we recreate Figure 4 after dropping health care occupations. Females continue to display a high degree of concentration in job and living conditions associated with risk of getting the virus, though with less extreme values for some of the components. In particular, both Proximity and Exposure to Disease now show much closer to zero

\footnotetext{
${ }^{5}$ Chernoff and Warman (2020) find that in the U.S., females are much more likely than males to be in an occupation with high viral transmission risk.
} 
Figure 4: Regression of risk factors on occupation-level characteristics: all occupations

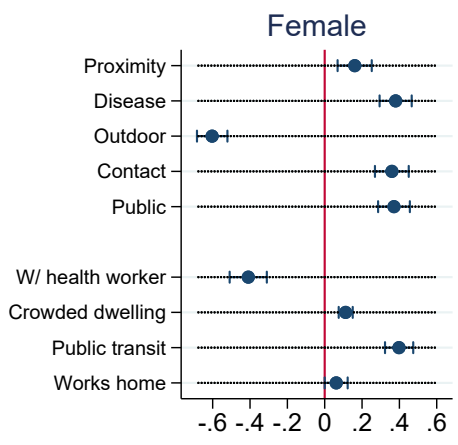

- Estimate $\longmapsto 95 \% \mathrm{Cl}$

Recent immigrant

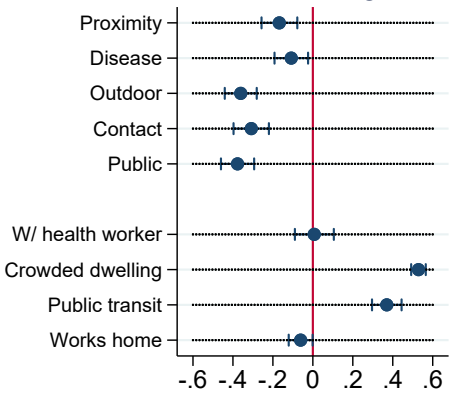

- Estimate $\longmapsto 95 \% \mathrm{Cl}$

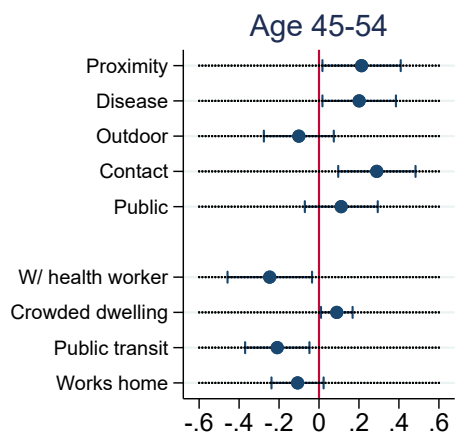

- Estimate $\longmapsto 95 \% \mathrm{Cl}$

Low education

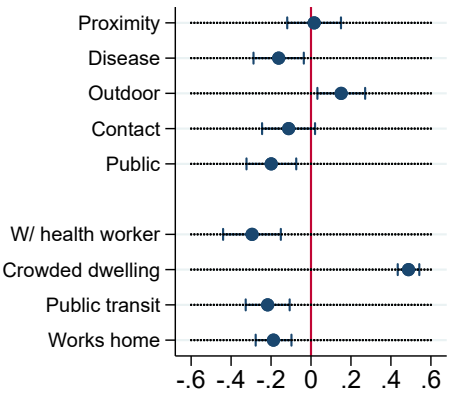

- Estimate $\longmapsto 95 \% \mathrm{Cl}$

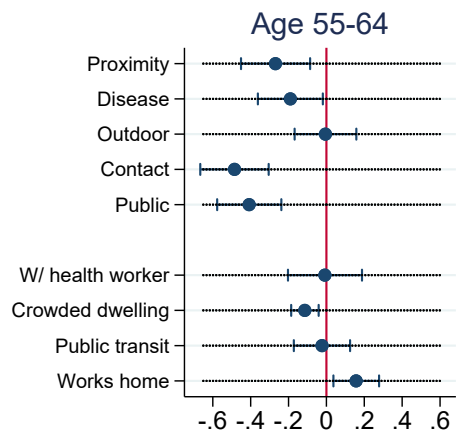

- Estimate $\longmapsto 95 \% \mathrm{Cl}$

Low income

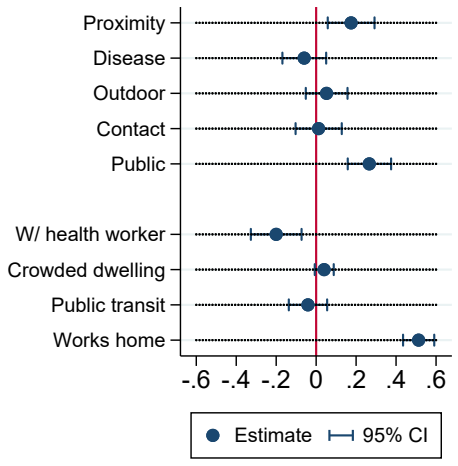

Notes: Point estimates and 95\% confidence intervals of risk components regressed on demographic characteristics of 4-digit NOC occupations. Results come from multivariate regressions of each risk component on the set of demographic characteristics. Each panel presents the marginal effect of the corresponding characteristic in each of these regressions. 
Figure 5: Regression of risk factors on occupation-level characteristics: excluding health occupations
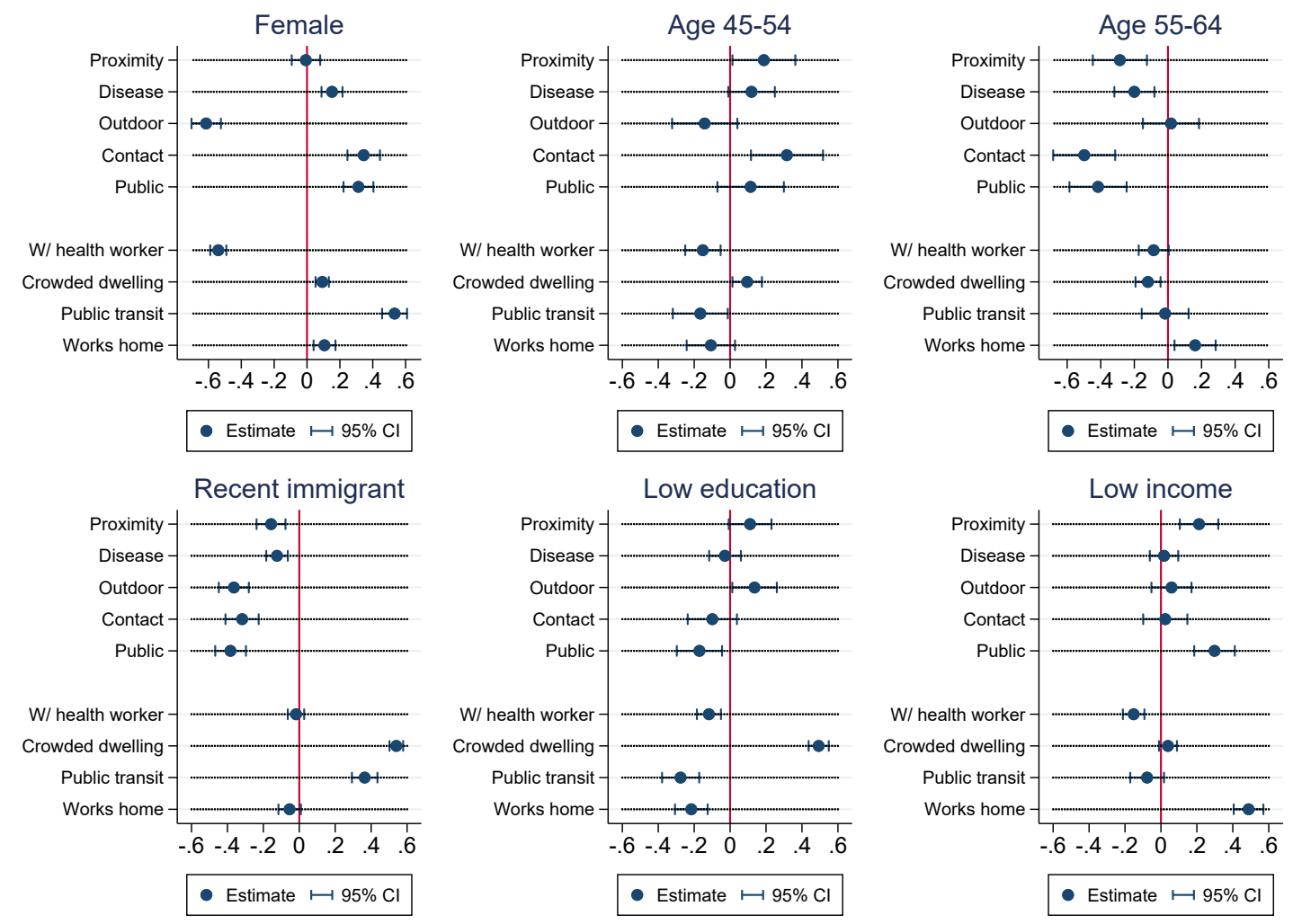

Notes: Point estimates and $95 \%$ confidence intervals of risk components regressed on demographic characteristics of 4-digit NOC occupations. Results come from multivariate regressions of each risk component on the set of demographic characteristics. Each panel presents the marginal effect of the corresponding characteristic in each of these regressions.

effects of gender but the other factors maintain similar values to those we witness when including health occupations. For recent immigrants, we again see low job characteristic risk but high living arrangement risk. Thus, our conclusions are not being driven by the special situation for health occupations.

For occupations with high proportions of low educated and low income workers, there is no consistent pattern in the set of occupational characteristics nor in the home characteristics of workers.

Figure 3 indicates that occupations with a high proportion of 45-54 year old workers are associated with greater viral transmission risk, while those with many 55-64 year olds are lower risk. The corresponding panels in Figure 4 show that these two age groups are essentially mirror images in terms of workplace characteristics, with 45-54 year olds being in jobs with greater proximity, disease risk, contact with others (particularly the 
Figure 6: Quantile regression of risk on occupation-level characteristics: all occupations
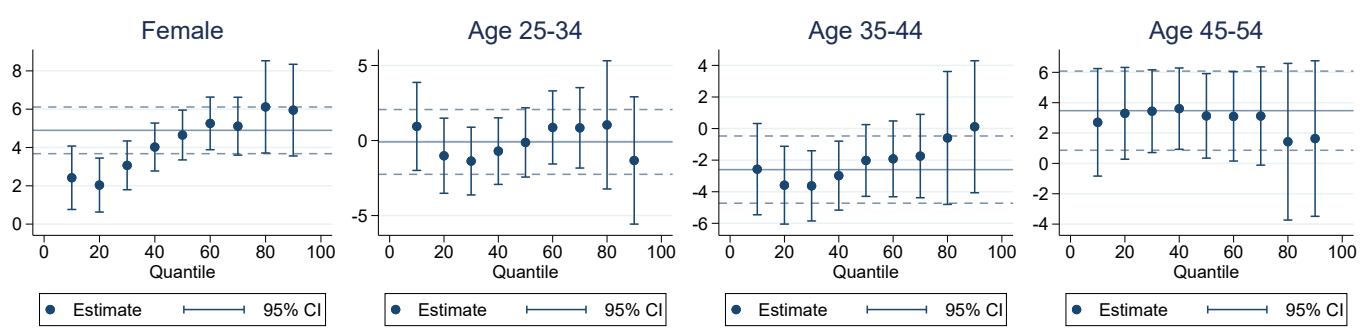

Age 65-74
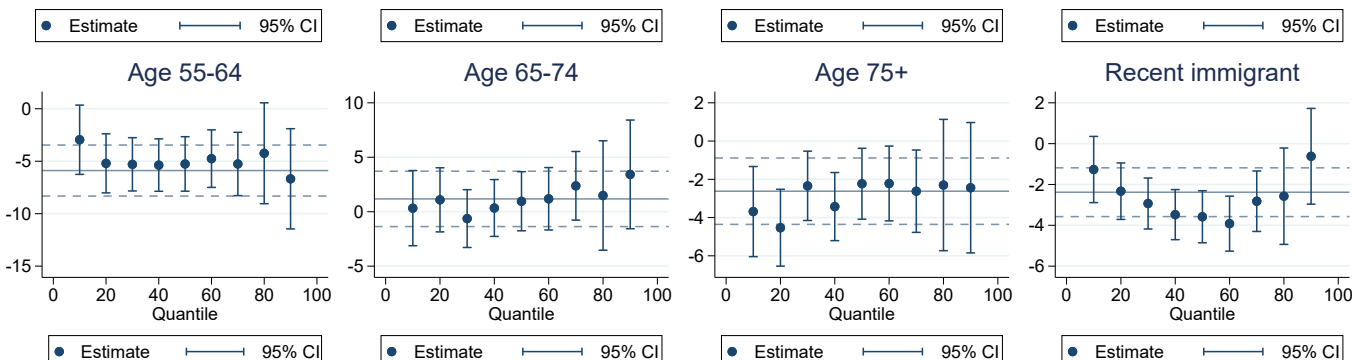

Age $75+$

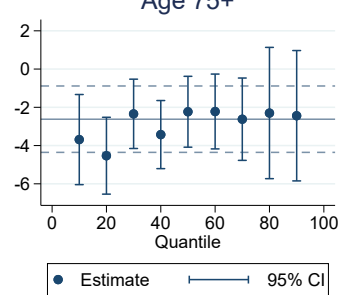

Recent immigrant

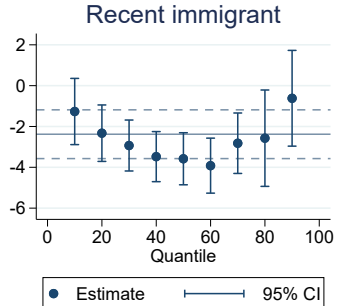

Low education

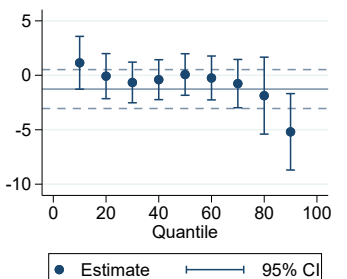

Low income

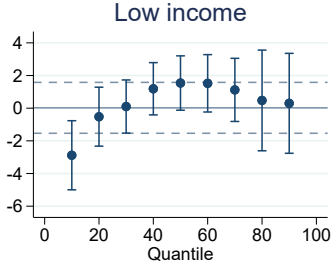

\begin{tabular}{llll}
\hline - Estimate $\longmapsto 95 \% \mathrm{Cl}$ & $\longmapsto$ \\
\hline
\end{tabular}

Notes: Point estimates and 95\% confidence intervals of VSE Risk Index regressed on demographic characteristics of 4-digit NOC occupations. Solid horizontal lines reproduce estimates presented in Figure 3, and dashed lines, the corresponding $95 \%$ confidence intervals.

public) and 55-64 year olds being the opposite. We do not have an explanation for these differences but note that they hold up even when controlling for immigrant status, education level and low income status.

To characterize the distribution of risk more completely, we also estimate nine quantile regressions (for quantiles $0.1,0.2, \ldots$, and 0.9 ), using the same set of variables as in Figure 3, Panel B. We present the corresponding estimated coefficients in Figure 6. The effect of a one-standard deviation increase in the proportion of female workers is always positive. Moreover, it is smaller at the bottom of the risk distribution and greater at the top. Hence, risk is distributed more unequally in high-female proportion occupations than in low-female proportion occupations, with female dominated occupations being particularly concentrated in high risk characteristics. The results for high immigrant occupations indicate that their distribution of risk is more right skewed than the low immigrant occupations, which could relate to a greater tendency to have lower contact with the public. 
Figure 7: Employment Loss, for All and by Demographics
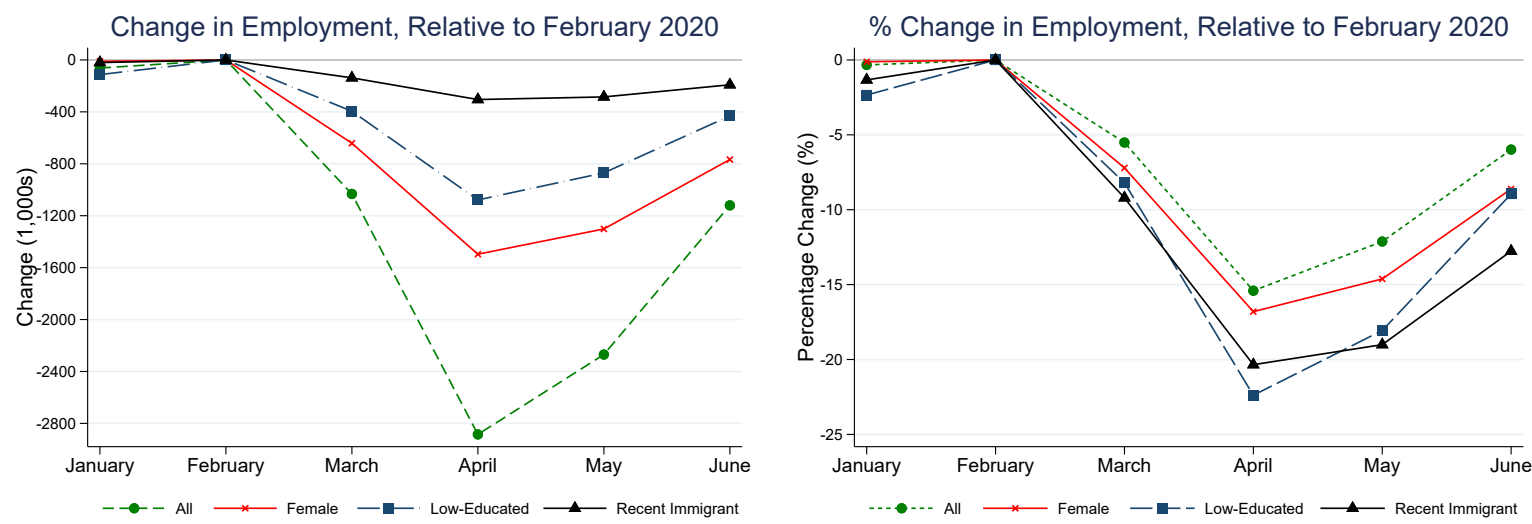

Notes: Changes in employment are computed relative to February and percent changes are normalized using the February level of employment. Employment incorporates both being at work and being absent from work.

\section{Who Bears the Risk of Job Loss?}

In this section, we investigate how the loss of employment has been distributed across workers in the Canadian economy, using monthly data from the LFS from January to June of 2020. As has been widely reported, employment losses during the initial stages of the pandemic shutdown are far-and-away the largest recorded during the postwar era (Lemieux et al. (2020)). Employment has since rebounded, but is still well below preCOVID levels. In Figure 7, we show employment losses in both absolute and percentage changes, relative to February 2020 employment levels, for all workers, as well as separately for female, immigrant and low-educated workers.

To provide context, in the left panel of Figure 8, we plot percentage changes in employment for all workers and our demographic sub-groups for the 2008/9 recession. In particular, we plot percentage changes relative to September 2008 for the period from September 2008 through April 2009 - a period running from one definition of the start of the recession through to its trough. The patterns in this figure reflect the standard pattern that recessions are most harmful for the most economically marginalized: lower educated and immigrant workers (see Jaimovich and Siu (2020)). Moreover, the 2008/9 recession reflects the standard finding that women tend to face smaller job losses than men in recessions.

The 2020 recession shown in Figure 7 also included larger negative employments effect for immigrant and lower educated workers. This is particularly evident in the percentage changes shown on the right, in Panel B. While total employment fell by $15.4 \%$ (for all 
Figure 8: Employment Loss, for All and by Demographics, 2008 Recession
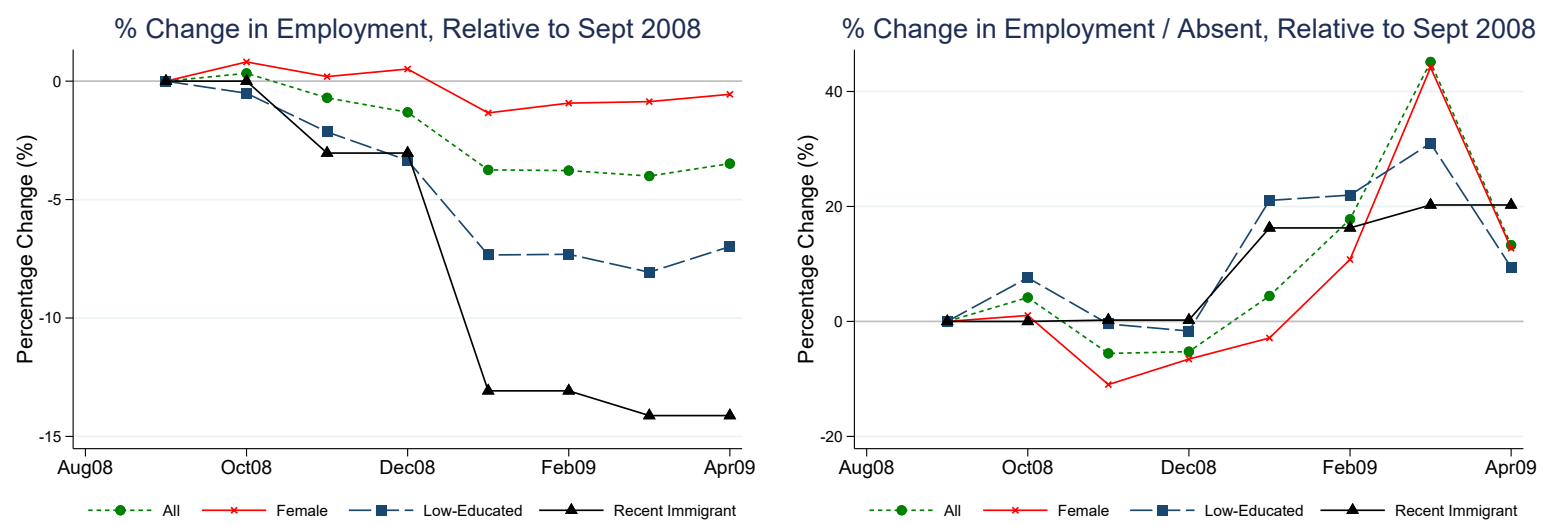

Notes: Percent changes are normalized using the September 2008 level of employment. Employment incorporates both being at work and being absent from work.

workers) between February and April, it fell by $22.4 \%$ for the less educated (those with high school attainment or less), and by $20.4 \%$ for recent immigrants (landed immigrants, arrived in Canada between 2010 and 2020 inclusively). A similar discrepancy is evident, particularly for immigrants, when we include the subsequent partial recovery, April to June. By comparison, in the 2008/9 recession immigrant employment followed the same pattern of an initial sharp drop followed by a relatively anemic recovery but the drop amounted to a smaller, 15\% decline. For the low educated, similarly, employment losses were larger than for the higher educated but, again, much smaller than in the 2020 recession (an $8 \%$ decline compared to over $20 \%$ in the current recession).

The most striking characteristic of the current recession is that job loss for female workers has also been disproportionately high. In the 2008/9 recession, female job loss was relatively negligible, with the male decline being over $6 \%$ greater. This is also true in earlier recessions, arising because of the greater concentration of male workers in both routine production occupations and in cyclically sensitive construction occupations. However, in the current "pandemic" recession, the pattern has been flipped: women have borne the disproportionate share of employment loss. Total employment fell by $15.4 \%$ (for all workers) between February and April, and by 6.0\% between February and June. By contrast, female employment fell by $16.8 \%$ and by $8.6 \%$ over those same time periods. Put differently, women have accounted for $68.5 \%$ of total job loss since February, despite accounting for $47.6 \%$ of employment averaged over January and February of 2020. Job loss effects are certainly more evident for low educated and immigrant workers; however, there is reason to call this a "she-cession", when viewed in comparison to earlier 
Figure 9: Increase in Being Employed but Absent, for All and by Demographics
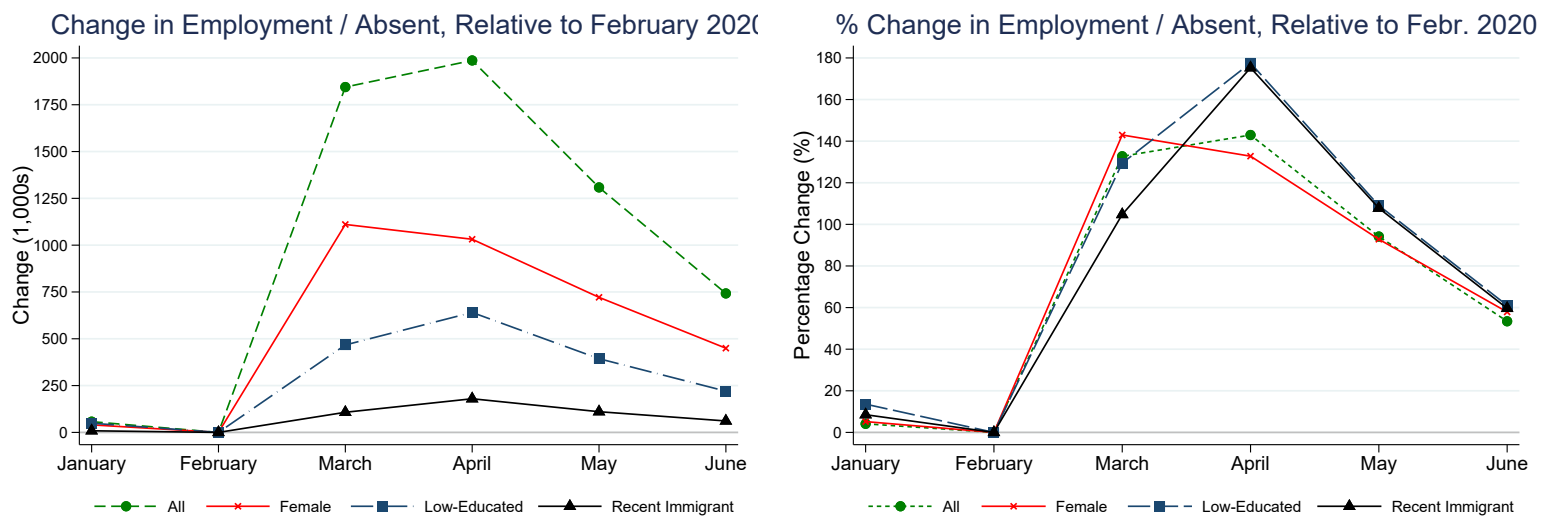

Notes: Changes in employment are computed relative to February and percent changes are normalized using the February level of employment.

recessions. ${ }^{6}$ Thus, women bear a greater burden from both types of risk created by the pandemic: risk of contracting the virus at work and risk of job loss. We investigate the relationship between these two risks in the next section.

The employment numbers in Figure 7 correspond to the standard Statistics Canada definition of employment, including everyone who reports that they are employed during the LFS survey week. However, employment can have different forms and the LFS also asks respondents whether they are: employed and present at work; employed and absent from work for the whole week; and, if absent, whether they were being paid. In Figure 9, we show changes in the numbers of individuals who report being employed but absent from work for the survey week. We provide numbers for the 2008/9 recession for comparison in the right panel of Figure 8.

Comparison to the left panel of Figure 7 affords an understanding of the magnitude of work disruption. From February to April, over $2.8 \mathrm{M}$ jobs were lost. Figure 9 indicates the extent to which that understates the amount of "work lost": during that same time period, an additional 2.0 million individuals were employed but absent from work, amounting to almost $\frac{3}{4}$ 's $(71 \%)$ of job loss. From April to June there was a reduction in the number who were employed/absent, mirroring the recovery in employment, but still remained far from pre-COVID values.

Comparing Figure 9 to the right panel of Figure 8, we see that the use of the employed but absent state has been much greater in the 2020 recession than in the previous one. For all workers combined, the employed but absent state increased in size by about $40 \%$ in

\footnotetext{
${ }^{6}$ For characterization of the U.S. experience along demographic lines, see Cortes and Forsythe (2020).
} 
the $2008 / 9$ recession but by $140 \%$ in the 2020 recession. This likely reflects the nature of the 2020 recession as one that was purposefully induced, with firms unsure about when they could re-open and, so, interested in maintaining an attachment to their workers. Gender effects again switch signs between the two recessions, with women having smaller increases (or larger decreases) in their probability of being employed but absent in the 2008/9 recession and slightly larger increases in probability in the first part of the 2020 recession, but the differences are small. The effects for the low educated and immigrants also switch signs, with immigrants and the low educated being less pushed into the employed but absent state in the later part of the 2008/9 recession than higher educated and non-immigrant workers but more in that state in the most recent months of this recession.

\section{The Relationship between Employment and Viral Transmission Risks}

Viral risk and employment risk are not independent. From the public health perspective of minimizing viral transmission, policy would prioritize shutting down sectors where viral risk is greatest. To the extent this is true, the two risks may interact and exacerbate negative impacts. As discussed in Section 3, women face greater viral risk and, from the numbers in Section 4, also experienced greater employment loss.

We take a first step at assessing these interactions in Figure 10. In each panel, employment losses are displayed separately for health- and non-health-related occupations. ${ }^{7}$ Non-health occupations are further disaggregated by (2019 employment weighted) terciles of the VSE Risk Index. We do this because health-related occupations - while associated with the highest levels of viral transmission risk according to our methodology - exhibited very different employment dynamics compared to other high (viral) risk occupations, due to their obvious essential-service function.

Figure 10 makes it clear that job loss was not experienced evenly across the distribution of viral transmission risk: occupations with high viral risk scores lost many more jobs than lower risk occupations. Relative to February, top tercile occupations lost about $1.5 \mathrm{M}$ jobs, as compared to around 500,000 jobs for bottom tercile occupations. By June, employment in low-risk occupations exceeded February levels, whereas high-risk occupations were still well short. In percentage terms, by June the high-risk occupations were

\footnotetext{
${ }^{7}$ Health-related occupations are defined based on the NOC classification which includes the two-digit codes $30,31,32$, and 34 .
} 
Figure 10: Employment Loss by VSE Risk Index
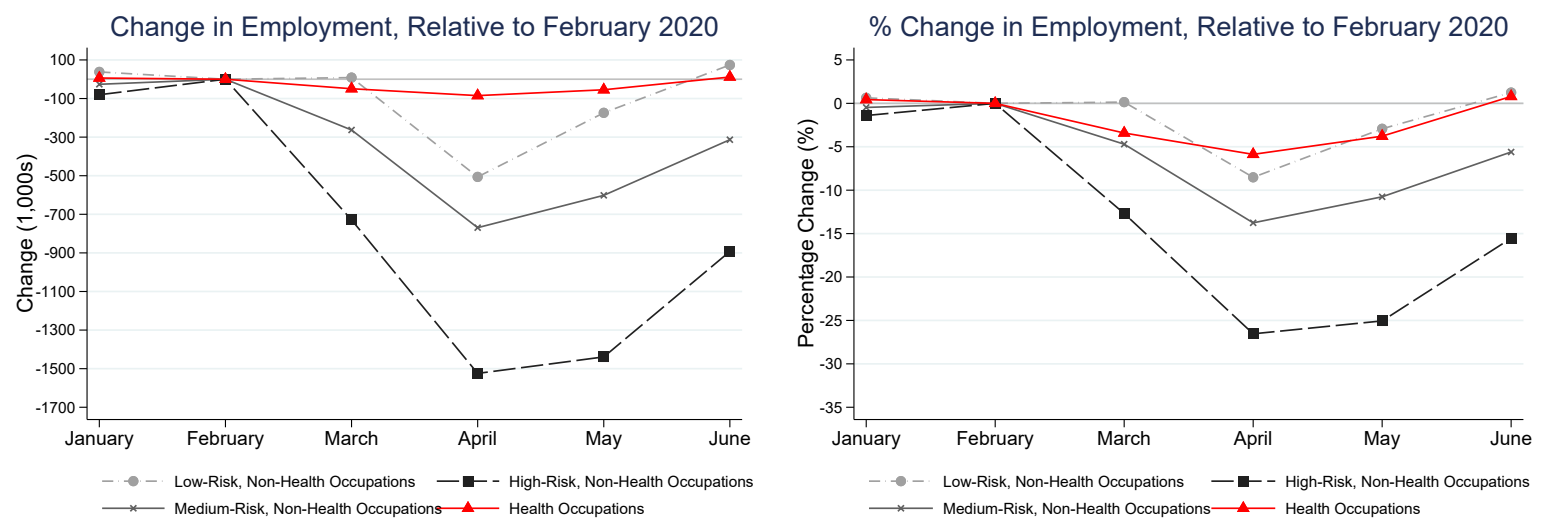

Notes: Changes in employment are computed relative to February and percent changes are normalized using the February level of employment. Non-health occupations are classified into three equal categories (low/medium/high), based on their VSE Risk Index, weighted by the share of 2019 employment in a given 4-digit occupation. Employment incorporates both being at work and being absent from work.

still $15.5 \%$ below their February employment levels, medium risk occupations were 5.6\% below, while both low risk and health occupations were above their February levels. In comparison, Figure 11 shows employment changes for the 2008/9 recession broken down by the same Covid virus risk categories. In that recession, what would years later turn out to be the high virus risk occupations actually experienced employment increases and it was the low risk occupations that had the greatest employment declines. This serves as a form of validation of the risk index since one would expect occupations ranked as high risk to be more likely to be shut down when the virus is present but not necessarily when it is not. Interestingly, health occupations were relatively 'recession-proof' in both recessions.

Figure 12 presents employment numbers by viral risk separately for our main demographic groups. Here, the interaction of viral risk and job loss amplifies effects for disadvantaged groups. For the low educated, employment in high-risk occupations dropped by $34 \%$ between February and April and recovered only to about $20 \%$ below its February level by June. For immigrants, the loss is more severe, with June employment still almost $30 \%$ below its February level. For immigrants, June employment in health occupations is well below its February level, though overall employment is slightly above. For women, the employment loss in high-risk occupations is slightly greater than that displayed in Figure 10; employment loss in middle risk occupations is large relative to men by the end of our period. Note that the non-health occupation terciles are defined for the overall population and from Section 3, women are over-represented in higher risk occupations. 
Figure 11: Employment Loss, By Virus Risk Categories, 2008 Recession

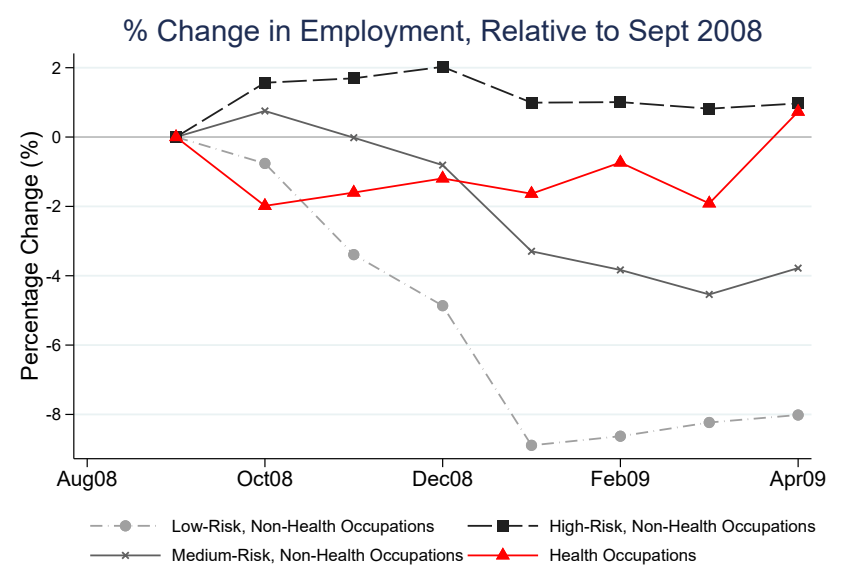

Notes: Percent changes are normalized using the September 2008 level of employment. Non-health occupations are classified into three equal categories (low/medium/high), based on their VSE Risk Index, weighted by the share of 2019 employment in a given 4-digit occupation. Employment incorporates both being at work and being absent from work.

This leads to the higher job losses for women discussed above in Section 4.

Tables 1 and 2 present regression analysis to further illustrate that job loss was not experienced evenly across the distribution of viral transmission risk. We do so at the granular, 4-digit occupation level (as opposed to risk terciles). Table 1 presents results for employment change in non-health occupations between February and April; Table 2 presents results for April to June. In both tables, absent workers are excluded from the definition of employment, and change in employment is expressed relative to occupational employment observed in February.

The first column considers the bivariate relationship between occupational employment change and the VSE Risk Index, and reinforces the findings of Figure 10. Table 1 indicates a much larger drop in employment for higher risk occupations between February and April; Table 2 indicates no significant difference in employment recovery by VSE Risk Index from April to June. In combination with the difference in baseline employment changes, as captured by the estimated regression constants, riskier occupations have exhibited larger job losses over the pandemic to date, February to June.

Columns 2 and 3 consider the marginal effects of the various characteristics included in the VSE Risk Index. In Column 2 of Table 1, we regress changes in employment on occupational characteristics alone. We view this as informative given the emphasis on O*NET characteristics in other work (see, for instance, Dingel and Neiman (2020)). The coefficient signs, and the relative size and significance, accords with intuition. In 
Figure 12: Detailed Employment Loss by VSE Risk Index and Demographics
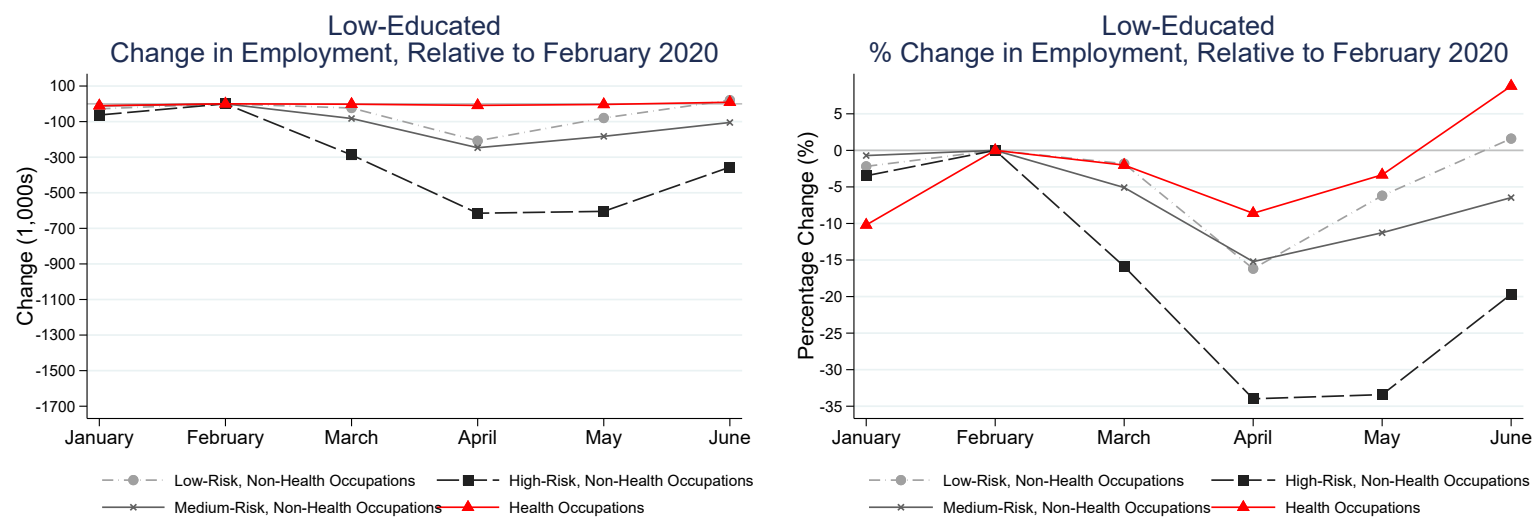

Recent Immigrants

Change in Employment, Relative to February 2020

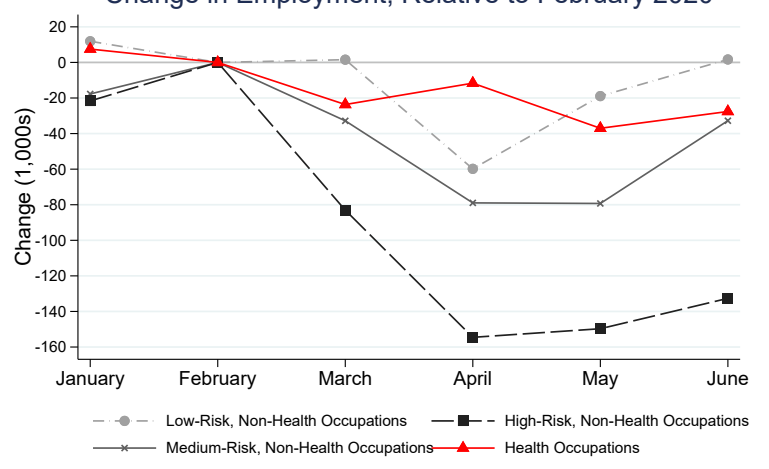

Recent Immigrants

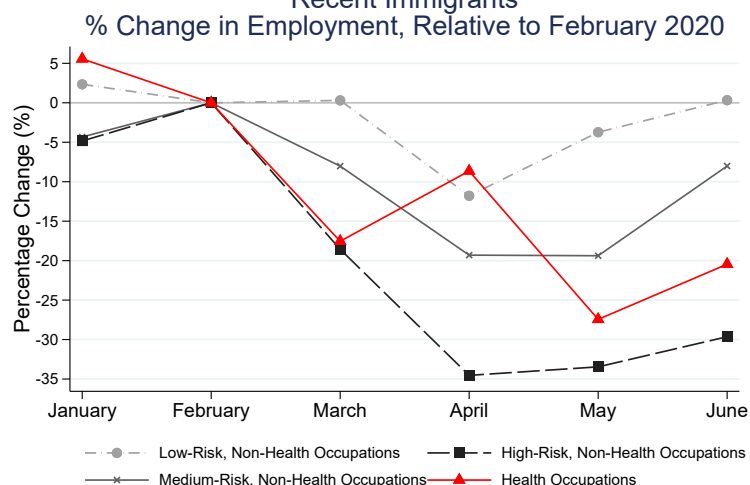

Females

Change in Employment, Relative to February 2020

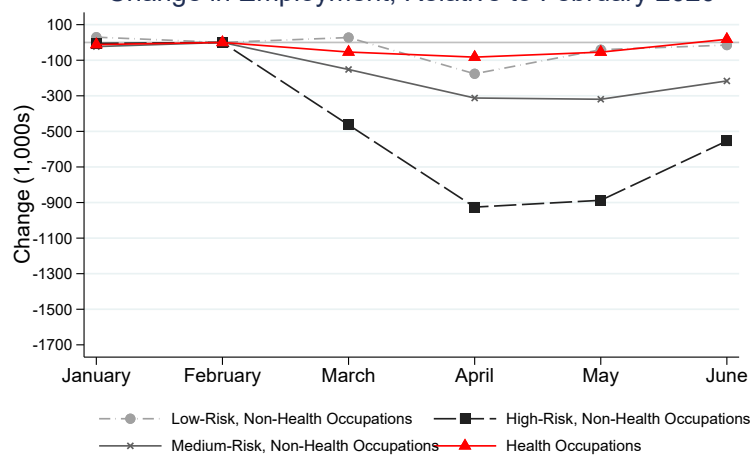

Females

\% Change in Employment, Relative to February 2020

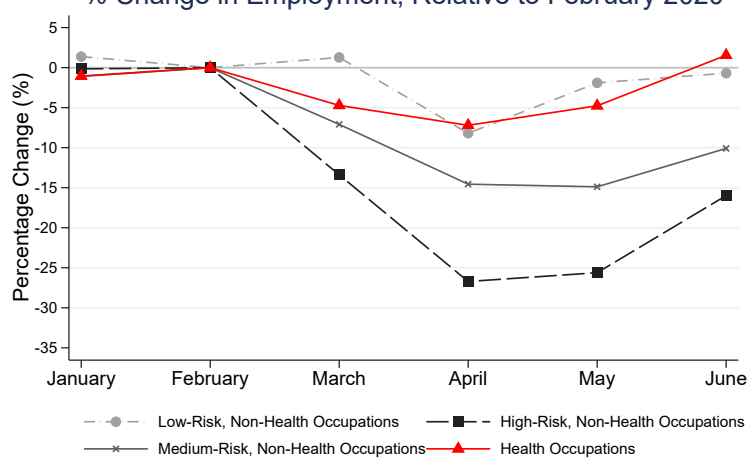

Notes: Changes in employment are computed relative to February and percent changes are normalized using the February level of employment. Non-health occupations are classified into three equal categories (low/medium/high), based on their VSE Risk Index, weighted by the share of 2019 employment in a given 4-digit occupation. Employment incorporates both being at work and being absent from work. 
Table 1: Regression of Change in Employed, At Work (February-April, relative to February) on VSE Risk Index and Components

\begin{tabular}{|c|c|c|c|c|c|c|c|}
\hline \multirow{2}{*}{ Independent Variable: } & \multicolumn{7}{|c|}{ Occupational Employment Change } \\
\hline & $(1)$ & $(2)$ & $(3)$ & (4) & $(5)$ & (6) & $(7)$ \\
\hline Std. VSE Risk Index & $\begin{array}{l}-0.145^{* * *} \\
(0.0241)\end{array}$ & & & & $\begin{array}{l}-0.122^{* * *} \\
(0.0203)\end{array}$ & & $\begin{array}{l}-0.118^{* * *} \\
(0.0179)\end{array}$ \\
\hline \multicolumn{8}{|l|}{ Std. O*NET Measures } \\
\hline Proximity & & $\begin{array}{l}-0.172^{* * *} \\
(0.0227)\end{array}$ & $\begin{array}{l}-0.129 * * * \\
(0.0268)\end{array}$ & $\begin{array}{l}-0.146^{* * *} \\
(0.0277)\end{array}$ & & $\begin{array}{l}-0.144^{* * *} \\
(0.0277)\end{array}$ & \\
\hline Disease & & $\begin{array}{l}0.0468 \\
(0.0353)\end{array}$ & $\begin{array}{l}0.0387 \\
(0.0266)\end{array}$ & $\begin{array}{l}0.0235 \\
(0.0230)\end{array}$ & & $\begin{array}{l}0.0303 \\
(0.0286)\end{array}$ & \\
\hline Outexposed & & $\begin{array}{l}0.0410^{*} \\
(0.0200)\end{array}$ & $\begin{array}{l}0.0483 \\
(0.0252)\end{array}$ & $\begin{array}{l}0.0607^{*} \\
(0.0261)\end{array}$ & & $\begin{array}{l}0.0549 \\
(0.0310)\end{array}$ & \\
\hline Contact & & $\begin{array}{l}0.0811^{* * *} \\
(0.0222)\end{array}$ & $\begin{array}{l}0.0309 \\
(0.0230)\end{array}$ & $\begin{array}{l}0.0353 \\
(0.0245)\end{array}$ & & $\begin{array}{l}0.0370 \\
(0.0245)\end{array}$ & \\
\hline Public & & $\begin{array}{l}-0.0838^{* *} \\
(0.0250)\end{array}$ & $\begin{array}{l}-0.0595^{*} \\
(0.0248)\end{array}$ & $\begin{array}{l}-0.0444 \\
(0.0239)\end{array}$ & & $\begin{array}{l}-0.0417 \\
(0.0229)\end{array}$ & \\
\hline \multicolumn{8}{|l|}{ Std. Census Share Measures } \\
\hline Live with Health Worker & & & $\begin{array}{l}-0.0199 \\
(0.0328)\end{array}$ & $\begin{array}{l}-0.0160 \\
(0.0312)\end{array}$ & & $\begin{array}{l}-0.0236 \\
(0.0326)\end{array}$ & \\
\hline Unsuitable Dwelling & & & $\begin{array}{l}-0.0746^{* * *} \\
(0.0206)\end{array}$ & $\begin{array}{c}-0.00846 \\
(0.0254)\end{array}$ & & $\begin{array}{l}-0.0140 \\
(0.0414)\end{array}$ & \\
\hline Public Transit for Work & & & $\begin{array}{l}0.0353^{*} \\
(0.0162)\end{array}$ & $\begin{array}{l}0.0136 \\
(0.0184)\end{array}$ & & $\begin{array}{l}0.0154 \\
(0.0178)\end{array}$ & \\
\hline Working from Home & & & $\begin{array}{l}-0.0149 \\
(0.0125)\end{array}$ & $\begin{array}{l}-0.0150 \\
(0.0152)\end{array}$ & & $\begin{array}{l}-0.0145 \\
(0.0148)\end{array}$ & \\
\hline Low Education & & & & $\begin{array}{l}-0.0814^{* *} \\
(0.0264)\end{array}$ & $\begin{array}{l}-0.0958^{* * *} \\
(0.0171)\end{array}$ & $\begin{array}{c}-0.0769 * \\
(0.0295)\end{array}$ & $\begin{array}{l}-0.0942^{* * *} \\
(0.0178)\end{array}$ \\
\hline Female & & & & & & $\begin{array}{l}-0.0133 \\
(0.0305)\end{array}$ & $\begin{array}{c}-0.00682 \\
(0.0179)\end{array}$ \\
\hline Recent Immigrant & & & & & & $\begin{array}{l}0.00459 \\
(0.0328)\end{array}$ & $\begin{array}{l}-0.0151 \\
(0.0134)\end{array}$ \\
\hline Constant & $\begin{array}{l}-0.277^{* * *} \\
(0.0234)\end{array}$ & $\begin{array}{l}-0.291^{* * * *} \\
(0.0229)\end{array}$ & $\begin{array}{l}-0.272^{* * *} \\
(0.0213)\end{array}$ & $\begin{array}{l}-0.277^{* * *} \\
(0.0211)\end{array}$ & $\begin{array}{l}-0.259^{* * *} \\
(0.0169)\end{array}$ & $\begin{array}{l}-0.277^{* * *} \\
(0.0209)\end{array}$ & $\begin{array}{l}-0.255^{* * *} \\
(0.0193)\end{array}$ \\
\hline Observations & 458 & 458 & 458 & 458 & 458 & 458 & 458 \\
\hline
\end{tabular}

Notes:

[1] Table shows the estimated linear regression coefficients of the change in employment on standardized measures of viral transmission risk, where one observation corresponds to a 4-digit occupation.

[2] Standard errors are in parentheses and are clustered at the 2-digit occupation-level.

[3] Statistical significance is denoted by: ${ }^{* * *}$ at $1 \%$ level, ${ }^{* *}$ at $5 \%$ level, ${ }^{*}$ at $10 \%$ level.

[4] Health occupations are excluded from the sample.

[5] Regressions are weighted by the share of 2019 employment in a given 4-digit occupation. 
Table 2: Regression of Change in Employed, At Work (April-June, relative to February) on VSE Risk Index and Components

\begin{tabular}{|c|c|c|c|c|c|c|c|}
\hline \multirow{3}{*}{ Independent Variable: } & \multirow{2}{*}{\multicolumn{7}{|c|}{ Occupational Employment Change }} \\
\hline & & & & & & & \\
\hline & (1) & $(2)$ & (3) & (4) & $(5)$ & (6) & (7) \\
\hline Std. VSE risk index & $\begin{array}{l}0.0161 \\
(0.0267)\end{array}$ & & & & $\begin{array}{c}-0.00948 \\
(0.0313)\end{array}$ & & $\begin{array}{l}0.00778 \\
(0.0324)\end{array}$ \\
\hline \multicolumn{8}{|l|}{ Std. O*NET Measures } \\
\hline Proximity & & $\begin{array}{l}0.0746^{* *} \\
(0.0226)\end{array}$ & $\begin{array}{l}0.0322 \\
(0.0321)\end{array}$ & $\begin{array}{l}0.0463 \\
(0.0322)\end{array}$ & & $\begin{array}{l}0.0250 \\
(0.0436)\end{array}$ & \\
\hline Disease & & $\begin{array}{l}-0.0687^{*} \\
(0.0267)\end{array}$ & $\begin{array}{l}-0.0601^{* *} \\
(0.0186)\end{array}$ & $\begin{array}{l}-0.0478^{*} \\
(0.0182)\end{array}$ & & $\begin{array}{l}-0.0659 \\
(0.0392)\end{array}$ & \\
\hline Outexposed & & $\begin{array}{l}0.0574 \\
(0.0422)\end{array}$ & $\begin{array}{l}0.0569 \\
(0.0560)\end{array}$ & $\begin{array}{l}0.0470 \\
(0.0547)\end{array}$ & & $\begin{array}{l}0.0562 \\
(0.0695)\end{array}$ & \\
\hline Contact & & $\begin{array}{l}-0.0825^{* *} \\
(0.0285)\end{array}$ & $\begin{array}{l}-0.0476 \\
(0.0271)\end{array}$ & $\begin{array}{l}-0.0511 \\
(0.0279)\end{array}$ & & $\begin{array}{l}-0.0460 \\
(0.0307)\end{array}$ & \\
\hline Public & & $\begin{array}{l}0.0478 \\
(0.0351)\end{array}$ & $\begin{array}{l}0.0293 \\
(0.0334)\end{array}$ & $\begin{array}{l}0.0172 \\
(0.0329)\end{array}$ & & $\begin{array}{l}-0.00217 \\
(0.0244)\end{array}$ & \\
\hline \multicolumn{8}{|l|}{ Std. Census Share Measures } \\
\hline Live with Health Worker & & & $\begin{array}{l}0.00326 \\
(0.0228)\end{array}$ & $\begin{array}{l}0.000102 \\
(0.0228)\end{array}$ & & $\begin{array}{l}0.00329 \\
(0.0338)\end{array}$ & \\
\hline Unsuitable Dwelling & & & $\begin{array}{l}0.0596^{* * *} \\
(0.0157)\end{array}$ & $\begin{array}{l}0.00627 \\
(0.0214)\end{array}$ & & $\begin{array}{l}0.108 \\
(0.0651)\end{array}$ & \\
\hline Public Transit for Work & & & $\begin{array}{l}-0.0261 \\
(0.0171)\end{array}$ & $\begin{array}{l}-0.00867 \\
(0.0189)\end{array}$ & & $\begin{array}{c}-0.00586 \\
(0.0214)\end{array}$ & \\
\hline Working from Home & & & $\begin{array}{l}-0.0128 \\
(0.0175)\end{array}$ & $\begin{array}{l}-0.0128 \\
(0.0200)\end{array}$ & & $\begin{array}{c}-0.00720 \\
(0.0207)\end{array}$ & \\
\hline Low Education & & & & $\begin{array}{l}0.0656^{* *} \\
(0.0231)\end{array}$ & $\begin{array}{l}0.104^{* *} \\
(0.0306)\end{array}$ & $\begin{array}{l}0.0103 \\
(0.0367)\end{array}$ & $\begin{array}{l}0.103^{* *} \\
(0.0340)\end{array}$ \\
\hline Female & & & & & & $\begin{array}{l}0.0165 \\
(0.0461)\end{array}$ & $\begin{array}{c}-0.0348^{*} \\
(0.0134)\end{array}$ \\
\hline Recent Immigrant & & & & & & $\begin{array}{l}-0.0938 \\
(0.0542)\end{array}$ & $\begin{array}{l}-0.0316 \\
(0.0289)\end{array}$ \\
\hline Constant & $\begin{array}{l}0.193^{* * *} \\
(0.0256)\end{array}$ & $\begin{array}{l}0.206^{* * *} \\
(0.0202)\end{array}$ & $\begin{array}{l}0.190^{* * *} \\
(0.0167)\end{array}$ & $\begin{array}{l}0.194^{* * *} \\
(0.0164)\end{array}$ & $\begin{array}{l}0.174^{* * *} \\
(0.0188)\end{array}$ & $\begin{array}{l}0.189^{* * *} \\
(0.0166)\end{array}$ & $\begin{array}{l}0.188^{* * *} \\
(0.0214)\end{array}$ \\
\hline Observations & 458 & 458 & 458 & 458 & 458 & 458 & 458 \\
\hline
\end{tabular}

Notes:

[1] Table shows the estimated linear regression coefficients of the change in employment on standardized measures of viral transmission risk, where one observation corresponds to a 4-digit occupation.

[2] Standard errors are in parentheses and are clustered at the 2-digit occupation-level.

[3] Statistical significance is denoted by: *** at $1 \%$ level, $* *$ at $5 \%$ level, ${ }^{*}$ at $10 \%$ level.

[4] Health occupations are excluded from the sample.

[5] Regressions are weighted by the share of 2019 employment in a given 4-digit occupation. 
particular, Proximity is clearly associated with employment loss: of all standardized O*NET measures, its estimated effect is largest and is significant at the $1 \%$ level. ${ }^{*}$ Column 2 of Table 2 indicates that more proximate occupations experienced stronger recovery April to June, though the effect is noticeably smaller. This finding rationalizes the emphasis that the literature has placed on proximity in analysis of employment dynamics during the crisis (see, for instance, Mongey et al. (2020) and Montenovo et al. (2020)).

The third column includes worker characteristics. Inclusion of the census-based covariates diminishes the point estimates on almost all the $\mathrm{O}^{*} \mathrm{NET}$ characteristics and drives them to insignificance. The main exception is proximity, which continues to have an effect that is statistically significant at the $1 \%$ level. However, its effect is diminished by about a third during the initial downturn, and by an order of magnitude for the April to June change results. What emerges is a sizeable relationship of employment change to the (standardized) share of workers in an occupation living in an unsuitable dwelling, significant at the $1 \%$ in Tables 1 and 2. This is consistent with the interpretation that in Column 2, an occupation's proximity score and other job characteristics are, to some extent, proxying for the extent to which an occupation employs economically marginalized individuals, as captured by the share living in crowded residences (see Mongey and Weinberg (2020)).

To explore this point further, and to bridge to the analysis in Section 4, we include the share of an occupation's workers with at most high school educational attainment as a regressor. This is done in Column 4 where viral risk characteristics are included individually, and in Column 5 where they are included via the VSE Risk Index. As is well known, an occupation's educational requirement is a very good proxy for its wage and/or income.

The inclusion of the proportion of workers in the occupation with low education generates several notable findings. First, proximity continues to be a key determinant of job loss, though to a lesser extent than when not including education and worker characteristics. Second, the proportion of workers living in an unsuitable dwelling no longer has a coefficient that is either economically substantial or statistically significant. Thus, that worker condition seemed actually to be proxying for occupations having low education (and, hence, low wage) workers. Third, and strikingly, the effect of the share of workers with high school education or less is large and significant at the $1 \%$ level

\footnotetext{
${ }^{8}$ Jobs that require dealing with the Public also experienced greater job loss. In interpreting the positive coefficient on Outdoors, recall that a greater tendency for working outdoors is associated with less viral risk. Finally, greater Contact with others is a mitigating factor, as occupations with higher scores tend to be supervisory/managerial occupations that experienced less job loss.
} 
in Table 1 (and at the $5 \%$ level in Table 2). Hence, lower educated occupations have been more cyclically sensitive during the pandemic. This represents greater economic risk for low wage/education occupations that - importantly - cannot be accounted for by differences in viral transmission risk, as embodied in the viral risk characteristics we consider. In other words, higher virus risk is associated with greater job loss, but the disproportionate job loss of lower educated workers occurred for reasons independent of the virus risk of their occupations. This corroborates the lack of relationship between education and virus risk in Section 3 but much larger declines in employment for this group in Section 4. Seemingly, the pandemic resulted in labour hoarding of more highlyeducated workers relative to the low-educated, even after accounting for viral risk.

The same is not true for differences along the dimensions of gender and immigrant status. This is evidenced in Columns 6 and 7, where we include the occupations' proportion of females and recent immigrants. The estimated coefficients on these occupational characteristics are small and statistically insignificant, that is, controlling for the riskiness of the occupation drives the female effect (Which we know is sizeable from Section 4) to zero. Hence, an important takeaway can be drawn regarding the 'she-cession' effect discussed in Section 4: this is accounted for by the fact that women work in riskier occupations, as opposed to firms choosing to fire women before men in any given occupation. ${ }^{9}$ This contrasts with low-educated workers seemingly being used as the absorptive buffer for employment change. In a sense, they act as insurance for the higher educated. Interestingly, the same is not true of recent immigrants, the effects of which are insignificant in the last columns of the table.

Overall, our conclusion is that the large employment losses experienced by women and the low educated (especially measured relative to patterns in the 2008/9 recessions) reflect systematic risk exposures of different types. For women, it is their greater exposure to disease in the work environment. For the low educated, it is their greater exposure to job loss during downturns that is in evidence, also, in earlier recessions. Thus, as many people have stated, the Covid pandemic has exposed deep-seated inequalities in the labour market. Our risk index allows us to investigate the nature of the inequalities and how they have been important in this pandemic. Interestingly, they point to independent problems for the two groups: the employment problems for women do not reflect extra exposure to job loss once we control for the riskiness of their jobs and the employment

\footnotetext{
${ }^{9}$ In regressions, not reported here, in which we include the proportion female without controlling for the proportion recent immigrant and the proportion low educated, the estimated female effect is also small and statistically insignificant. Thus, what drives this effect to zero is controlling for the riskiness of an occupation not controlling for other demographic/skill characteristics.
} 
problems of the low educated do not reflect any differential exposure to virus risk. The nature of the risk revealed in the pandemic is multi-faceted but important in each case.

\section{Adjustment Mechanisms}

The findings for employment change presented above reflect the net result of exposure to risk combined with adjustments to mitigate that risk. The larger job losses for females, low educated workers, and recent immigrants in Figure 7 may reflect these groups facing more negative demand shocks for their labour, lesser opportunities to mitigate those shocks, or a combination of the two. For example, lower and more educated workers in a firm may face different declines in demand for their services to the extent they can be, say, replaced with technology. But even if the declines in demand do not differ, more educated workers may have a greater ability to adjust through, for example, working from home. In this section we consider potential adjustment channels for workers as well as insurance mechanisms that could help workers smooth the employment shocks they face. More specifically, we consider adjustment through being kept on as an employee and being paid even though the worker is absent from work; being an absent employee but not paid; and shifting to working from home. We also consider intra-household risk sharing as an insurance mechanism.

\subsection{Adjustment by being Employed but Absent from Work}

Recall that in Section 4 we documented a large increase in the "employed but absent from work" status during the pandemic that is substantially larger than what was observed in the 2008/9 recession. In this section, we look more closely at this form of employment adjustment, examining changes in the number of individuals in four key categories using monthly LFS data: employed and at work in the LFS survey week; (employed but) absent from work and being paid; (employed but) absent from work and not being paid; ${ }^{10}$ and not employed. In Figure 13, we present changes in the number of individuals in each of these states relative to February, 2020 in both absolute and percentage terms for our main groups of interest: low- and high-educated workers (first row), women and men (second row), and (recent) immigrants and non-immigrants (third row).

For each of the groups, the left column (containing changes in absolute numbers) makes clear that the unprecedented increase in "employed but absent" that we observed

\footnotetext{
${ }^{10}$ Both the employed/absent categories are based on full-week absences.
} 


\section{Figure 13: Breakdown of Employment Loss by Demographics}
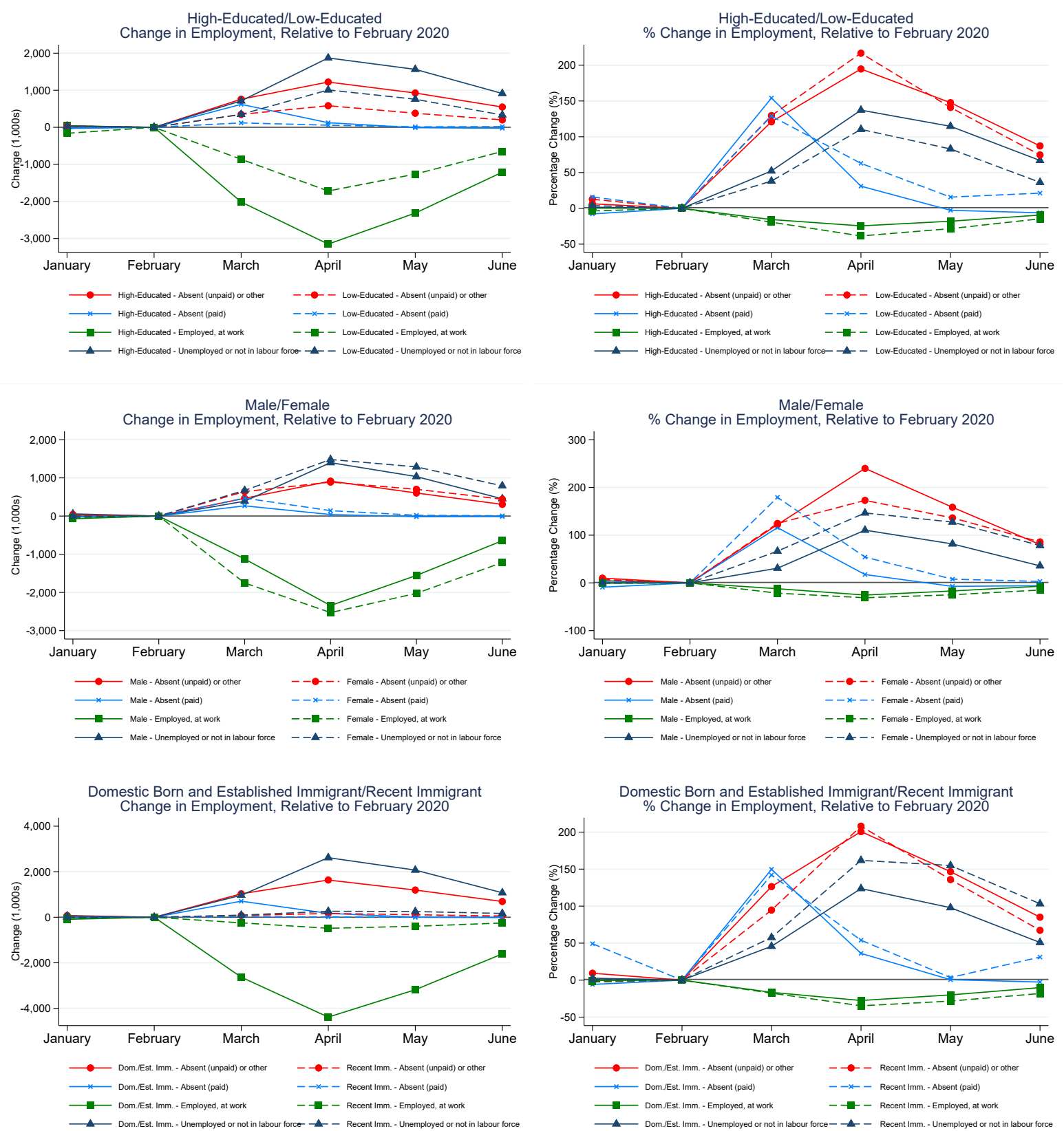

Notes: Changes in employment are computed relative to February and percent changes are normalized using the February level of employment. 
in Section 4 did not represent an unprecedented increase in workers who were paid for their absence. By April, and certainly by May and June, there is very little increase in the number of workers who were both absent and paid relative to February. ${ }^{11}$ The small changes in absent/paid are more obvious, in relation to the other changes observed in labour market status. Hence, the increase in absenteeism largely represents an increase in lost employment income. This is important because firm labour hoarding by keeping workers on the payroll but not actually requiring them to be at work would act as a form of insurance from the worker's perspective. Essentially, that form of insurance did not exist after March.

The education break downs in the first row of Figure 13 reflect our earlier observation that lower educated workers faced relatively larger declines in employed and increases in being working/absent. As discussed above, low-educated workers make up about onequarter of total employment. But as indicated in the top left panel of Figure 13, their employed/working loss was nearly half as large as that of those with more education, measured either February-April or February-June. As a result, they experienced proportionately greater loss in percent terms. The falls in employed/working for both education groups are allocated as approximately two-thirds being due to not working and one-third to being employed but absent from work.

The middle row of Figure 13 shows that female employed/work losses were greater than for men. For women, employed/working declines came from greater percentage increases in being unemployed/not in the labour force and lower increases in being employed/absent from work than for men. Finally, recent immigrants faced similar percentage increases in being employed/absent but larger increases in being unemployed/nonemployed than other workers. That is, they are relatively more likely to be simply thrown out of work without a maintained connection to the firm.

As we discussed earlier, the employed/absent/paid state represents a potential form of income insurance for workers - though it turns out to be one that is little used. It is less clear how to think about the employed/absent/unpaid state. Being in this state does not help the worker by mitigating their income loss. In that sense, it is a clearly worse state than being employed and at work and a similar state to simply being unemployed. Seeing a group with more individuals in the employed/absent/unpaid state would be assessed as bad for that group in the same way as seeing them with more unemployed individuals. But being employed/absent/unpaid represents a remaining connection to

\footnotetext{
${ }^{11}$ Expressed in percentage terms, a handful of the differences in June seem large (e.g. for immigrants), but this reflects the small number of absent/paid individuals in February, the reference period.
} 
the firm that may allow a more rapid return to work in which case having greater access to this state confers something of an advantage to a group.

To understand the nature of the employed/absent categories, in Figure 14 we examine the probability of being employed/working in June for individuals who were not employed/working in April. To do this, we take advantage of the 'mini-panel' nature of the LFS. Respondents are included in the LFS for 6 consecutive months with $\frac{1}{6}$ of the sample rotated out in each month and being replaced by a new, incoming group. Thus, for those present in the LFS in April, two-thirds of them will also be interviewed in the June LFS. We examine the two-thirds of April respondents who will still be present in the June interviews and who are not in the employed/working state. We break them down into five groups: employed/absent/paid; employed/absent/unpaid; temporary layoffs; other unemployed; and not in the labour force. For each group, we calculate the proportion who are employed/working in June. We present these proportions for the temporary layoffs, unemployed, and not in the labour force in order to provide a benchmark for the employed/absent groups. ${ }^{12}$

Figure 14 contains plots of the employed proportions for workers from all demographic groups combined. We do not present the Not in the Labour Force state in order to simplify the figure. It always has the lowest probability of employment in June. The best non-working state in terms of future access to the employed/working state is employed/absent/paid with $61 \%$ or these individuals being the employed/working state in June. This is perhaps not surprising since it represents a situation in which the worker is still attached to the firm and the firm may want to have the individual work since they are still paying them. However, we have seen that this is a very small group and, so, potentially of limited interest. The absent/employed/not paid, in comparison, fit almost midway between the unemployed who report they are on temporary lay-off and the rest of the unemployed who, in principle, have no formal ongoing connection with their former employer. ${ }^{13}$ Thus, being employed/absent represents a connection to the firm that does have some value, though less than is reflected in being placed on temporary layoff.

Assessing whether any groups have benefited, relatively, from the expansion of the employed/absent state is not straightforward. From Figure 13 we know that more educated workers faced smaller declines in the employed/working state. Since this is the

\footnotetext{
${ }^{12}$ This is in the spirit of Jones and Riddell (2006) who compare transition rates into employment as a means to determining how to group various non-employment groups into meaningfully similar, larger categories.

${ }^{13}$ Jones et al. (2020) show that temporary layoffs make up a very small proportion of the unemployed in normal months but half of the unemployed since March, 2020.
} 
Figure 14: Probability of Employment in June by Non-Work State in April

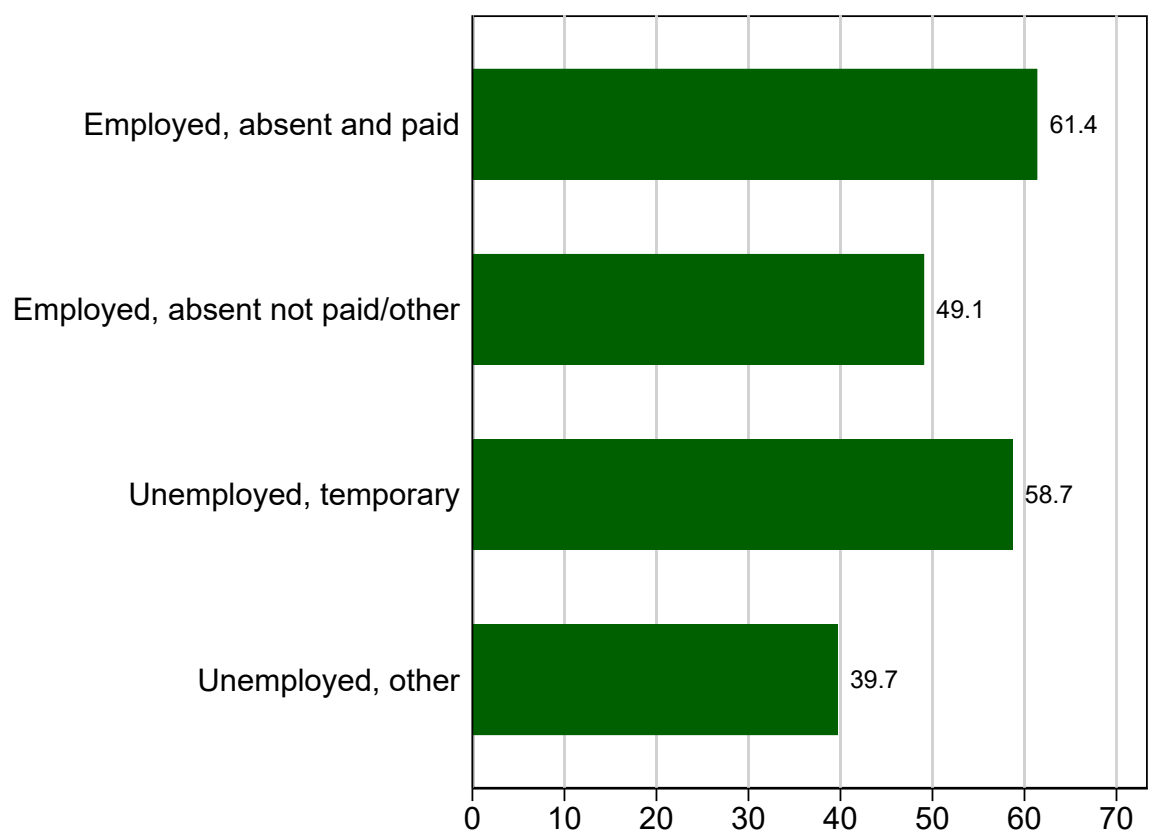

Notes: Proportions of people who were in each of the listed states in April, 2020 who were employed and at work in the LFS survey week in June, 2020. Based on longitudinal LFS data.

preferred labour market state, we can conclude that the combination of labour demand shocks and adjustments through labour hoarding have been relatively favourable to high educated workers. However, conditional on not being employed/working, the low educated were relatively more likely to move into the employed/absent state rather than the non-employed state. This represents a relative advantage in re-connecting to work in the future for those not currently working. In the gender breakdown, on the other hand, the patterns all point in the same direction. Men faced smaller declines in employed/working and, for those who were not in this state, larger increases in being employed/absent relative to being nonemployed. Thus, females faced larger increases in the least desirable state and larger declines in the most desirable state. The same is true for recent immigrants: they have had both larger declines in employed/working and larger increases in being nonemployed.

In Figure 15, we present ratios of the probabilities of being in the employed/working state for males/females, high educated/low educated, and non-immigrants/immigrants broken down by the different April labour market states. For each origin (non-working) state, females have a much lower probability of working in June. This relative disadvantage is greater in the employed/absent/not paid state than the unemployed (not on 
Figure 15: Probability of Employment in June by Non-Work State in April, Group Ratios
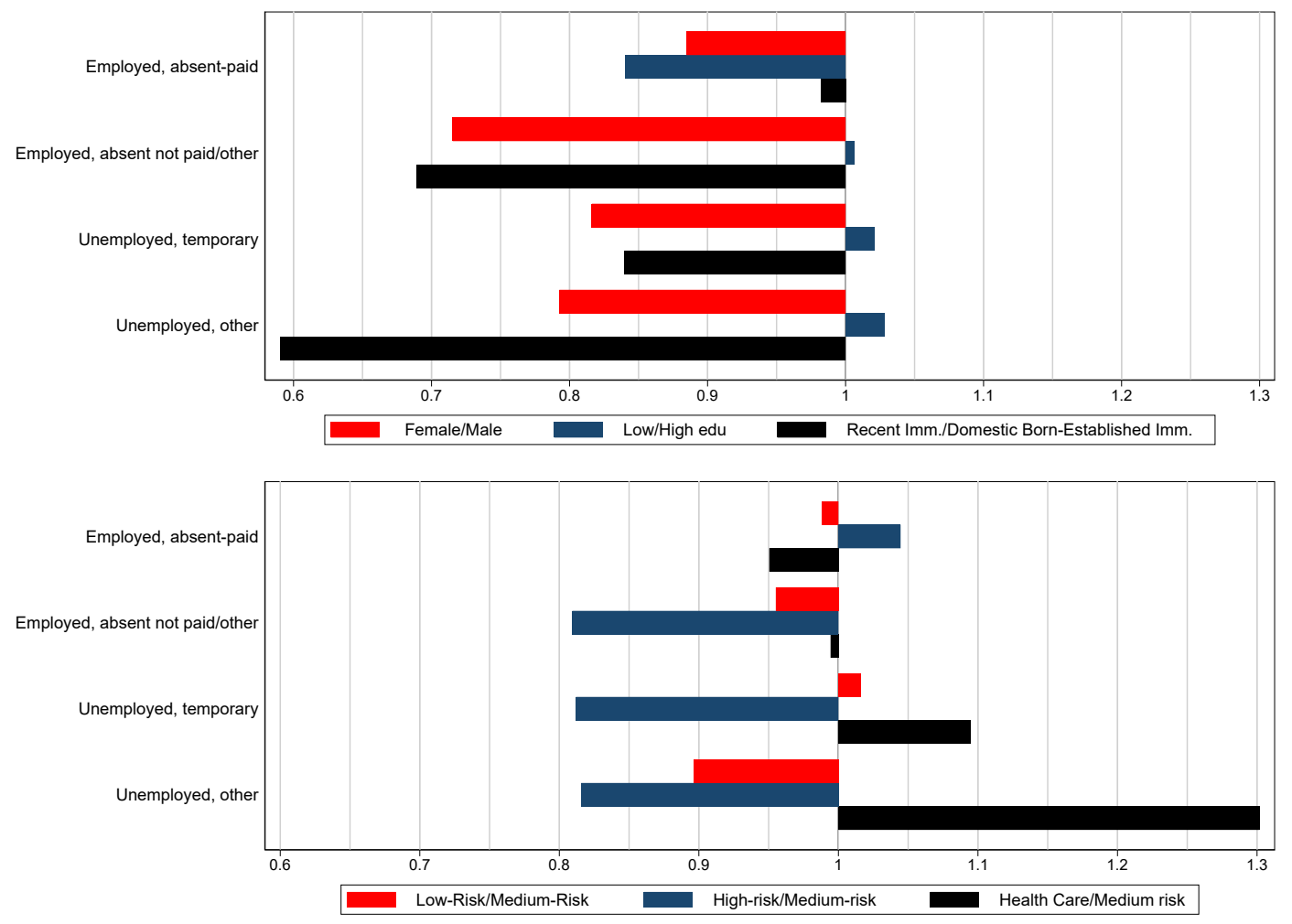

Notes: Ratios of proportions of people who were in each of the listed states in April, 2020 who were employed and at work in the LFS survey week in June, 2020. Based on longitudinal LFS data.

temporary layoff) state. Thus, women have lower access to the employed/absent option and even when they have it are at a greater than normal disadvantage in terms of being called back to work from that state. Recent immigrants, similarly, experience much lower rates of moving back to work in June but for them it is the unemployed who fare relatively worse in this regard. In contrast, there is little difference between the more and lower educated in terms of their probability of working in June for all categories other than the (small) employed/absent/paid state.

In summary, being employed but absent from work is a relatively advantageous state compared to being unemployed. Females and immigrants are both particularly disadvantaged in that they both are more likely to lose situations where they are employed/working and they are relatively more likely to be thrown into unemployment rather than keeping a connection to the firm through being employed but absent. Whatever non-working state they are in during April, they are less likely than either men or non-immigrants to be back at work in June. 


\subsection{Adjustment by Working from Home}

The greater probability of working for males/high educated/non-recent-immigrants may arise because of another adjustment mechanism that has risen to relevance in this particular recession: working from home. To establish the importance of this adjustment mechanism and who is able to access it, we estimate regressions using the proportion of workers in a given occupation who reported working from home as a response to the pandemic. In particular, in April, the LFS introduced a question asking workers if they worked from home in the reference week but usually worked outside the home. In April, May and June, only one of the six rotations was asked this question, while in July, five of the six rotations were asked. ${ }^{14}$ The work from home variable is restricted to workers who were employed and not absent from work.

In Figure 16, we present the proportion of those who are employed/working who report that they are working at home but don't usually do so. Overall, in April through July, 2002, about one-fifth of these workers are newly working from home but there are substantial differences across groups. Women are more likely to have shifted their work to home. This may suggest an advantage to women in terms of having access to this adjustment mechanism but likely reflects a greater tendency for women relative to men to work from home in order to take care of children who can no longer go to school. In that sense, it would suggest an added work disadvantage for women to the extent that working from home with children present creates issues for productivity and career progress.

The biggest difference in working from home is between the low and high educated groups. A quarter of the high educated were newly working from home after the onset of Covid but only $6 \%$ of the low educated made this change. One way to put this difference in context is to do a simple counterfactual exercise in which we ask what the June employment level would have been for the low educated if their rate of working from home had increased to the same extent as the high educated. In doing this, we assume that the increase in people working from home would be drawn entirely from the set of non-workers rather than just a conversion from those who are working but not from home in June. In this sense, our counterfactual is an upper bound on what increasing the option of working from home would do to employment for the low educated. The counterfactual exercise yields an estimate of an increase by approximately 100,000 in the number of low educated employees in June, 2020. Going back to Figure 4, this

\footnotetext{
${ }^{14}$ While we do not use the July LFS for the rest of the analysis, due to the limited sample available for April to June, we included it for the work at home section augment the sample size.
} 
Figure 16: Probability of Newly Working from Home

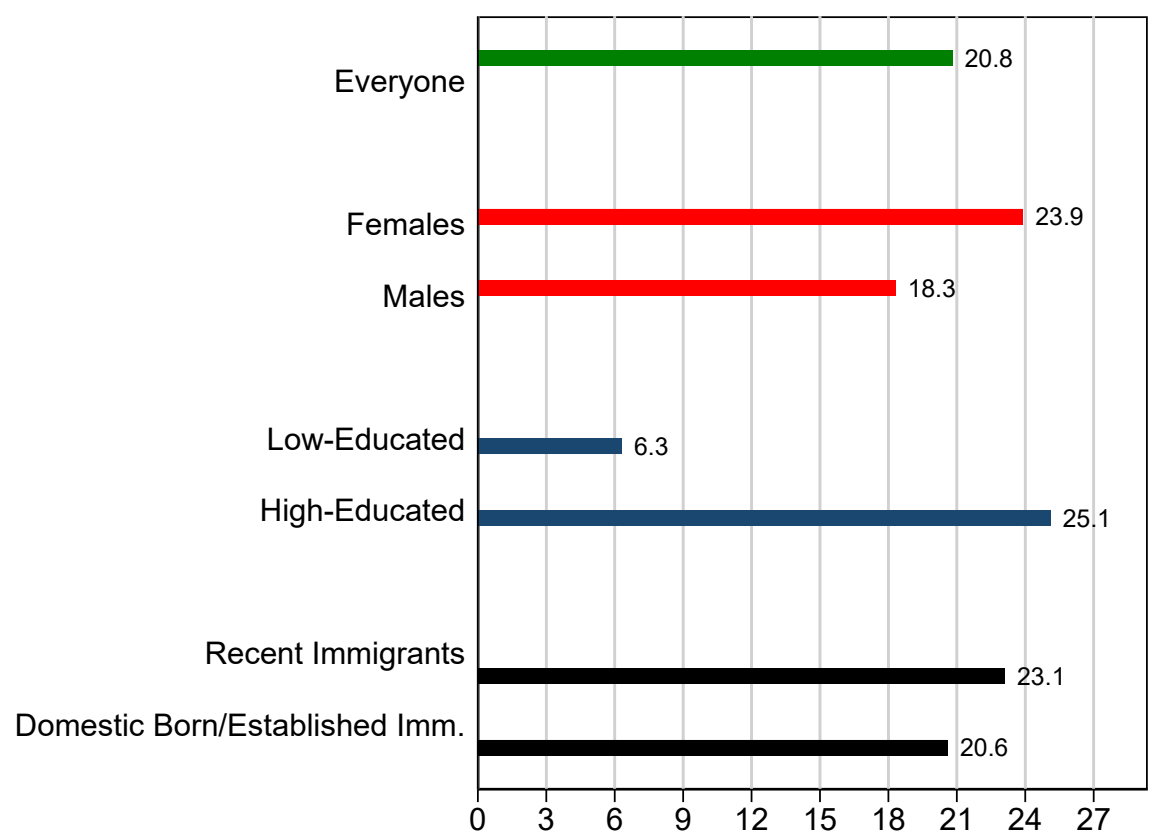

Notes: Proportions of employees who are employed and at work who report that they are working from home but do not usually do so. The data is from 1 rotation in the April, May, and June LFS and 5 rotations in the July LFS.

represents about a quarter of the total job loss for this group between February and June. In percentage terms, it would imply a decline of just over $6 \%$ instead of $9 \%$. This is the same percentage decline experienced by the high educated. That is, according to our rough counterfactual, we can completely account for the extra job loss for the low educated through their lower access to the 'work from home' adjustment mechanism.

Table 3 shows results from a linear probability model in which the dependent variable is a dummy variable equal to one for people who report that they are working from home but did not do so in the past. The samples are restricted to people who are employed and at work in the survey week. Panel A shows results for all workers, while Panels B, C and $\mathrm{D}$ focus on the proportion of low-educated, female and immigrant workers who report working from home. Strikingly, greater riskiness of an occupation is associated with lower work from home rates. In fact, results in Column 2 suggest that the very factors that increase risk, in particular Proximity with others and Dealing with the Public, are the factors associated with a lower propensity of transitioning to work-from-home. Turning to Column 3, it is notable that the negative correlation of work-from-home with $\mathrm{O}^{*} \mathrm{NET}$ occupational risk almost entirely disappears when we account for census-based, at-home 
worker risk characteristics. ${ }^{15}$ This fits with our observation that there is a substantial difference in working from home by education level, recalling that education level and characteristics such as living in a crowded dwelling are strongly correlated. Thus, lower educated workers do not have lower work from home rates because they tend to be in jobs such as those done in close proximity to others that cannot be shifted to home but because their home situations do not accommodate working from home. ${ }^{16}$ Putting these results together, the implication is that lower educated workers faced greater employment losses than their higher educated counterparts not because of the nature of their conditions at work but because of their living arrangements with more people living in a given number of rooms. In essence, in the face of a pandemic, inequalities in living conditions have generated inequalities in employment outcomes.

Looking at the propensity of different groups to work from home, we note that the relationship between the VSE Risk Index (and the individual risk factors) and workfrom-home is similar across all three groups, relative to their baseline propensity. In other words, while certain groups were more likely to transition to work-from-home, their response to viral risk was similar.

\footnotetext{
${ }^{15}$ Note that the set of home condition risk characteristics includes the proportion of people in the occupation who work from home in the 2016 Census. This does not enter as a significant predictor of the dependent variable because it refers to increased rates of working from home.

${ }^{16}$ Recall that lower educated workers did not face higher probabilities of being in high risk occupations such as those with greater proximity to others.
} 
Table 3: Regression of Proportion Working from Home on Risk Index and Risk Components

\begin{tabular}{|c|c|c|c|c|c|c|}
\hline & $(1)$ & $\begin{array}{l}\text { All } \\
(2) \\
\end{array}$ & $(3)$ & $(4)$ & $\begin{array}{c}\text { Female } \\
(5)\end{array}$ & $(6)$ \\
\hline VSE Risk Index (Factor) & $\begin{array}{l}-0.0733^{*} \\
(0.0312)\end{array}$ & & & $\begin{array}{l}-0.0879^{*} \\
(0.0352)\end{array}$ & & \\
\hline \multicolumn{7}{|l|}{$\mathrm{O}^{*}$ NET Measures } \\
\hline Proximity & & $\begin{array}{l}-0.0888^{* * *} \\
(0.0207)\end{array}$ & $\begin{array}{l}-0.00465 \\
(0.0158)\end{array}$ & & $\begin{array}{l}-0.0896^{* * *} \\
(0.0214)\end{array}$ & $\begin{array}{l}0.00273 \\
(0.0152)\end{array}$ \\
\hline Disease & & $\begin{array}{l}0.0167 \\
(0.0403)\end{array}$ & $\begin{array}{l}0.00705 \\
(0.0192)\end{array}$ & & $\begin{array}{l}0.0128 \\
(0.0402)\end{array}$ & $\begin{array}{l}0.0000441 \\
(0.0187)\end{array}$ \\
\hline Outexposed & & $\begin{array}{l}-0.0647^{* * *} \\
(0.0172)\end{array}$ & $\begin{array}{l}-0.0128 \\
(0.0106)\end{array}$ & & $\begin{array}{l}-0.0530^{*} \\
(0.0201)\end{array}$ & $\begin{array}{l}-0.00808 \\
(0.0164)\end{array}$ \\
\hline Contact & & $\begin{array}{l}0.0860^{* * * *} \\
(0.0204)\end{array}$ & $\begin{array}{l}0.000254 \\
(0.0110)\end{array}$ & & $\begin{array}{l}0.0934^{* * *} \\
(0.0228)\end{array}$ & $\begin{array}{l}-0.00186 \\
(0.0152)\end{array}$ \\
\hline Public & & $\begin{array}{l}-0.0700^{* *} \\
(0.0235)\end{array}$ & $\begin{array}{l}-0.0313^{*} \\
(0.0126)\end{array}$ & & $\begin{array}{l}-0.0930^{* * *} \\
(0.0261)\end{array}$ & $\begin{array}{l}-0.0482^{* *} \\
(0.0149)\end{array}$ \\
\hline \multicolumn{7}{|l|}{ Share from Census } \\
\hline Living with Health Worker & & & $\begin{array}{l}-0.0710^{* *} \\
(0.0231)\end{array}$ & & & $\begin{array}{l}-0.0536 \\
(0.0277)\end{array}$ \\
\hline Living in Unsuitable Dwelling & & & $\begin{array}{l}-0.128^{* * *} \\
(0.0161)\end{array}$ & & & $\begin{array}{l}-0.145^{* * *} \\
(0.0175)\end{array}$ \\
\hline Using Public Transit for Work & & & $\begin{array}{l}0.0974^{* * *} \\
(0.0112)\end{array}$ & & & $\begin{array}{l}0.101^{* * *} \\
(0.0140)\end{array}$ \\
\hline Working from Home & & & $\begin{array}{l}-0.0110 \\
(0.0126)\end{array}$ & & & $\begin{array}{l}-0.0147 \\
(0.0150)\end{array}$ \\
\hline Constant & $\begin{array}{l}0.200^{* * *} \\
(0.0329)\end{array}$ & $\begin{array}{l}0.179^{* * *} \\
(0.0281)\end{array}$ & $\begin{array}{l}0.197^{* * *} \\
(0.0191)\end{array}$ & $\begin{array}{l}0.222 * * * \\
(0.0348)\end{array}$ & $\begin{array}{l}0.204^{* * *} \\
(0.0311)\end{array}$ & $\begin{array}{l}0.231^{* * *} \\
(0.0240)\end{array}$ \\
\hline \multirow[t]{2}{*}{$\mathrm{N}$} & 454 & 454 & 454 & 408 & 408 & 408 \\
\hline & \multirow{2}{*}{\multicolumn{3}{|c|}{$\begin{array}{c}\text { Low Educated } \\
(2)\end{array}$}} & \multicolumn{3}{|c|}{ (4) Recent Immigrant } \\
\hline VSE Risk Index (Factor) & & & & $\begin{array}{c}-0.0694^{*} \\
(0.0322)\end{array}$ & & \\
\hline \multicolumn{7}{|l|}{$\mathrm{O}^{*} \mathrm{NET}$ Measures } \\
\hline Proximity & & $\begin{array}{l}-0.0597^{* * *} \\
(0.0159)\end{array}$ & $\begin{array}{l}0.00375 \\
(0.0130)\end{array}$ & & $\begin{array}{l}-0.0903^{* * *} \\
(0.0240)\end{array}$ & $\begin{array}{l}-0.00248 \\
(0.0211)\end{array}$ \\
\hline Disease & & $\begin{array}{l}0.0112 \\
(0.0313)\end{array}$ & $\begin{array}{l}0.00480 \\
(0.0174)\end{array}$ & & $\begin{array}{l}0.0191 \\
(0.0471)\end{array}$ & $\begin{array}{l}0.00871 \\
(0.0261)\end{array}$ \\
\hline Outexposed & & $\begin{array}{l}-0.0569^{* *} \\
(0.0192)\end{array}$ & $\begin{array}{l}-0.0107 \\
(0.0132)\end{array}$ & & $\begin{array}{l}-0.0635^{* * *} \\
(0.0172)\end{array}$ & $\begin{array}{l}-0.00921 \\
(0.0116)\end{array}$ \\
\hline Contact & & $\begin{array}{l}0.0642^{* * *} \\
(0.0174)\end{array}$ & $\begin{array}{c}-0.00806 \\
(0.0120)\end{array}$ & & $\begin{array}{l}0.0920^{* * *} \\
(0.0228)\end{array}$ & $\begin{array}{l}0.00206 \\
(0.0152)\end{array}$ \\
\hline Public & & $\begin{array}{l}-0.0707^{* *} \\
(0.0259)\end{array}$ & $\begin{array}{l}-0.0384^{*} \\
(0.0180)\end{array}$ & & $\begin{array}{l}-0.0687^{*} \\
(0.0267)\end{array}$ & $\begin{array}{l}-0.0273 \\
(0.0167)\end{array}$ \\
\hline \multicolumn{7}{|l|}{ Share from Census } \\
\hline Living with Health Worker & & & $\begin{array}{l}-0.0676^{* *} \\
(0.0230)\end{array}$ & & & $\begin{array}{l}-0.0691^{*} \\
(0.0302)\end{array}$ \\
\hline Living in Unsuitable Dwelling & & & $\begin{array}{l}-0.100^{* * *} \\
(0.0168)\end{array}$ & & & $\begin{array}{l}-0.134^{* * *} \\
(0.0169)\end{array}$ \\
\hline Using Public Transit for Work & & & $\begin{array}{l}0.0799 * * * \\
(0.0191)\end{array}$ & & & $\begin{array}{l}0.103^{* * *} \\
(0.0133)\end{array}$ \\
\hline Working from Home & & & $\begin{array}{l}-0.0177 \\
(0.0104)\end{array}$ & & & $\begin{array}{l}-0.0115 \\
(0.0140)\end{array}$ \\
\hline Constant & $\begin{array}{l}0.144^{* * *} \\
(0.0270)\end{array}$ & $\begin{array}{l}0.132^{* * *} \\
(0.0236)\end{array}$ & $\begin{array}{l}0.145^{* * *} \\
(0.0204)\end{array}$ & $\begin{array}{l}0.210^{* * *} \\
(0.0342)\end{array}$ & $\begin{array}{l}0.187^{* * *} \\
(0.0294)\end{array}$ & $\begin{array}{l}0.207^{* * *} \\
(0.0201)\end{array}$ \\
\hline $\mathrm{N}$ & 411 & 411 & 411 & 405 & 405 & 405 \\
\hline
\end{tabular}

Notes:

[1] Table shows the estimated linear regression coefficients of the proportion working from home on standardized measures of viral transmission risk, where one observation corresponds to a 4digit occupation.

[2] Standard errors are in parentheses and are clustered at the 2-digit occupation-level.

[3] Statistical significance is denoted by: *** at $1 \%$ level, $* *$ at $5 \%$ level, ${ }^{*}$ at $10 \%$ level.

[4] Health occupations are excluded from the sample.

[5] Regressions are weighted by the share of 2019 employment in a given 4-digit occupation. 


\subsection{Co-insurance and household structure}

Exposure to both virus and employment risk could be either amplified or mitigated within the household. In particular, if those who work in high risk occupations tend to live with others in high risk occupations then the exposure for a given household is magnified. We examine whether this is the case by looking at the virus risk scores for members of couples in February 2020. This provides us with a picture of the distribution of risk just prior to the pandemic and, thus, of the relative exposure of households to the risk that would soon arrive. As in our earlier examination of occupational risk, we divide the occupations into health occupations and then terciles of risk scores for the remaining, non-health occupations. We also include a non-working state which, as we will see, turns out to be important for our interpretations. The categories for females are presented in the columns while the categories for males are depicted in the rows. ${ }^{17}$ We show the percent of the total that each risk category comprises but also include the column percent (displayed in parentheses), which provides the distribution of risk across husbands for wives in a particular risk category. We carry out the analysis separately for low and high earning households, with low-earning households being those with weekly earnings below the median household weekly earnings in February 2020 and high-earning households having earnings above the median.

In Table 4a, we present these values for low-earning households. In both this table and in the subsequent table for high-earning households (in $4 \mathrm{~b}$ ), we can again see the overrepresentation of females in higher risk occupations. Women are also over-represented in the non-employment state, particularly in low-earning households. In contrast, the proportion of males in high-risk occupations is only slightly greater in the high-earning households (14.4 versus 16.6\%) and the proportion in health occupations is almost identical (both $2.9 \%$ ).

Females in high risk occupations and low-earning households have spouses who are quite evenly distributed across the categories other than health. This, though, is a difference relative to women in low and medium risk occupations and who are not working. In all of those cases, the proportion of husbands who are in high risk occupations is substantially below the proportions in the other (non-health) categories. Thus, women in low-earning are both more likely to be in high risk occupations and, conditional on working in a high risk occupation, are relatively more likely to have a spouse in a high risk occupation. Rather than mitigating their risk, marriage patterns tend to exacerbate

\footnotetext{
${ }^{17}$ We restrict this analysis to opposite sex married or common law couples since there were too few same-sex couples in the LFS to do this analysis separately.
} 
the virus risk faced by women. For men, as well, risk at work tends to be amplified by their spouse's working arrangements. If we focus on households in which both spouses are working, for males employed in high-risk occupations, $67 \%$ of the low income males and $58 \%$ of the high income males are with a spouse who is either in a high risk or health occupation. For males in health occupations, in both cases this is over $70 \%$. For high-earning households, females in high risk and health occupations tend to be coupled with males who are in low or medium risk occupations, suggesting some degree of diversification in terms of household risk.

Table 4a: Low-earning households

\begin{tabular}{|c|c|c|c|c|c|c|}
\hline Males & $\begin{array}{c}\text { Not } \\
\text { working }\end{array}$ & $\begin{array}{l}\text { Low } \\
\text { risk }\end{array}$ & $\begin{array}{l}\text { Medium } \\
\text { risk }\end{array}$ & $\begin{array}{l}\text { High } \\
\text { risk }\end{array}$ & $\begin{array}{c}\text { Health } \\
\text { occupation }\end{array}$ & Total \\
\hline Not working & $\begin{array}{c}20.3 \\
(45.5)\end{array}$ & $\begin{array}{c}3.4 \\
(27.5)\end{array}$ & $\begin{array}{c}3.9 \\
(26.3)\end{array}$ & $\begin{array}{c}5.4 \\
(24.8)\end{array}$ & $\begin{array}{c}1.8 \\
(28.5)\end{array}$ & 34.8 \\
\hline Low risk & $\begin{array}{c}9.5 \\
(21.3)\end{array}$ & $\begin{array}{c}4.7 \\
(37.4)\end{array}$ & $\begin{array}{c}3.1 \\
(20.8)\end{array}$ & $\begin{array}{c}4.8 \\
(22.2)\end{array}$ & $\begin{array}{c}1.3 \\
(20.6)\end{array}$ & 23.4 \\
\hline Medium risk & $\begin{array}{c}8.7 \\
(19.5)\end{array}$ & $\begin{array}{c}2.8 \\
(22.2)\end{array}$ & $\begin{array}{c}5.8 \\
(39.2)\end{array}$ & $\begin{array}{c}5.7 \\
(26.4)\end{array}$ & $\begin{array}{c}1.5 \\
(23.9)\end{array}$ & 24.5 \\
\hline High risk & $\begin{array}{c}5.2 \\
(11.7)\end{array}$ & $\begin{array}{c}1.3 \\
(10.1)\end{array}$ & $\begin{array}{c}1.8 \\
(12.2)\end{array}$ & $\begin{array}{c}5.2 \\
(23.9)\end{array}$ & $\begin{array}{c}0.9 \\
(14.0)\end{array}$ & 14.4 \\
\hline Health occupation & $\begin{array}{c}0.9 \\
(2.0)\end{array}$ & $\begin{array}{c}0.4 \\
(2.9)\end{array}$ & $\begin{array}{c}0.2 \\
(1.4)\end{array}$ & $\begin{array}{c}0.6 \\
(2.7)\end{array}$ & $\begin{array}{c}0.8 \\
(13.0)\end{array}$ & 2.9 \\
\hline Total & $\begin{array}{c}44.6 \\
(100.0)\end{array}$ & $\begin{array}{c}12.5 \\
(100.0)\end{array}$ & $\begin{array}{c}14.8 \\
(100.0)\end{array}$ & $\begin{array}{c}21.7 \\
(100.0)\end{array}$ & $\begin{array}{c}6.4 \\
(100.0)\end{array}$ & 100.0 \\
\hline
\end{tabular}

Notes: Earnings are based on the February 2020 household weekly earnings. Low earnings are households with below median earnings while high earnings defined as households with above median earnings. Column percentage in parentheses. 
Table 4b: High-earning households

\begin{tabular}{|c|c|c|c|c|c|c|}
\hline Males $\longrightarrow$ Females & $\begin{array}{c}\text { Not } \\
\text { working }\end{array}$ & $\begin{array}{l}\text { Low } \\
\text { risk }\end{array}$ & $\begin{array}{l}\text { Medium } \\
\text { risk }\end{array}$ & $\begin{array}{c}\text { High } \\
\text { risk }\end{array}$ & $\begin{array}{c}\text { Health } \\
\text { occupation }\end{array}$ & Total \\
\hline Not working & $\begin{array}{c}0.0 \\
(0.0)\end{array}$ & $\begin{array}{c}1.1 \\
(4.1)\end{array}$ & $\begin{array}{c}0.6 \\
(2.7)\end{array}$ & $\begin{array}{c}0.7 \\
(2.4)\end{array}$ & $\begin{array}{c}0.4 \\
(3.2)\end{array}$ & 2.8 \\
\hline Low risk & $\begin{array}{c}5.1 \\
(49.8)\end{array}$ & $\begin{array}{c}12.0 \\
(46.6)\end{array}$ & $\begin{array}{c}9.2 \\
(43.3)\end{array}$ & $\begin{array}{c}11.5 \\
(39.5)\end{array}$ & $\begin{array}{c}5.5 \\
(40.2)\end{array}$ & 43.3 \\
\hline Medium risk & $\begin{array}{c}3.6 \\
(35.0)\end{array}$ & $\begin{array}{c}8.9 \\
(34.8)\end{array}$ & $\begin{array}{c}8.0 \\
(37.6)\end{array}$ & $\begin{array}{c}9.7 \\
(33.4)\end{array}$ & $\begin{array}{c}4.2 \\
(30.8)\end{array}$ & 34.4 \\
\hline High risk & $\begin{array}{c}1.3 \\
(12.9)\end{array}$ & $\begin{array}{c}3.4 \\
(13.1)\end{array}$ & $\begin{array}{c}3.1 \\
(14.5)\end{array}$ & $\begin{array}{c}6.5 \\
(22.4)\end{array}$ & $\begin{array}{c}2.3 \\
(16.7)\end{array}$ & 16.6 \\
\hline Health occupation & $\begin{array}{l}0.2 \\
(2.4)\end{array}$ & $\begin{array}{c}0.4 \\
(1.4)\end{array}$ & $\begin{array}{c}0.4 \\
(1.8)\end{array}$ & $\begin{array}{c}0.7 \\
(2.3)\end{array}$ & $\begin{array}{c}1.3 \\
(9.1)\end{array}$ & 2.9 \\
\hline Total & $\begin{array}{c}10.2 \\
(100.0)\end{array}$ & $\begin{array}{c}25.7 \\
(100.0)\end{array}$ & $\begin{array}{c}21.2 \\
(100.0)\end{array}$ & $\begin{array}{c}29.1 \\
(100.0)\end{array}$ & $\begin{array}{c}13.8 \\
(100.0)\end{array}$ & 100.0 \\
\hline
\end{tabular}

Notes: Earnings are based on the February 2020 household weekly earnings. Low earnings are households with below median earnings while high earnings defined as households with above median earnings. Column percentage in parentheses.

In Figure 17, we examine risk sharing in terms of job loss for couples. Given that we are examining couples, we take a slightly different approach than in the rest of the paper. We restrict analysis to the January and February 2020 rotation samples since we are able to obtain pre-COVID occupation and household earnings information; then, using the longitudinal component of the LFS, we follow these two cohorts from February to June. We examine the employment outcomes in terms of occupational risk and household earnings which we define based on the February 2020 values. We categorize low risk households as those for which neither spouse worked in a high risk or health occupation in February and a high risk household as those for which at least one person of the couple worked in either a high risk or health occupation. We show the fraction of each earning/risk category for which both are employed, the male is employed and the female is not employed, the female is employed and the male is not employed, or both are not employed. 
Our analysis of job loss in Section 4 revealed that workers in occupations with higher VSE Risk Index scores experienced greater job loss. Here, we find the same viral riskjob loss relationship based on the household analysis. While there is a sizeable decline between February and April in terms of households in which both spouses are employed for all four risk-earnings groups, we find that household with at least one worker in an occupation with a high VSE Risk Index score see a disproportionate decline. This is true even though we have included health occupations in this group and health care job loss was minimal. The fraction of high earning/high risk households in which both members of the couple were employed declined from 94 percent in February to 72 percent in April, while the fraction for the low earning/high risk households declined from 64 to 46 percent over the same period. the low risk groups also experienced declines in the proportion of couples in which both were employed, but to a lesser degree.

We can get an assessment of within-family employment insurance by examining movements in the proportion of couples in which both were not employed. For low earning households of both risk levels, the decline in the proportion with both employed is almost exactly mirrored by the proportion in which neither worked. In contrast, in the high earnings households, the movement in the proportion of couples in which both are not working is minimal. That is, high earnings couples were able to continue with at least one member of the couple in work while low earnings couples were not. Thus, to the extent that low earnings are correlated with low education, the larger job losses for lower educated workers is amplified by their household matches. Lower educated (low earning) workers are more likely to have a spouse who also loses a job. Thus, they not only face greater job risk, they have lower intra-household insurance against that risk. 
Figure 17: Employment Outcomes by Household Earnings and Viral Risk
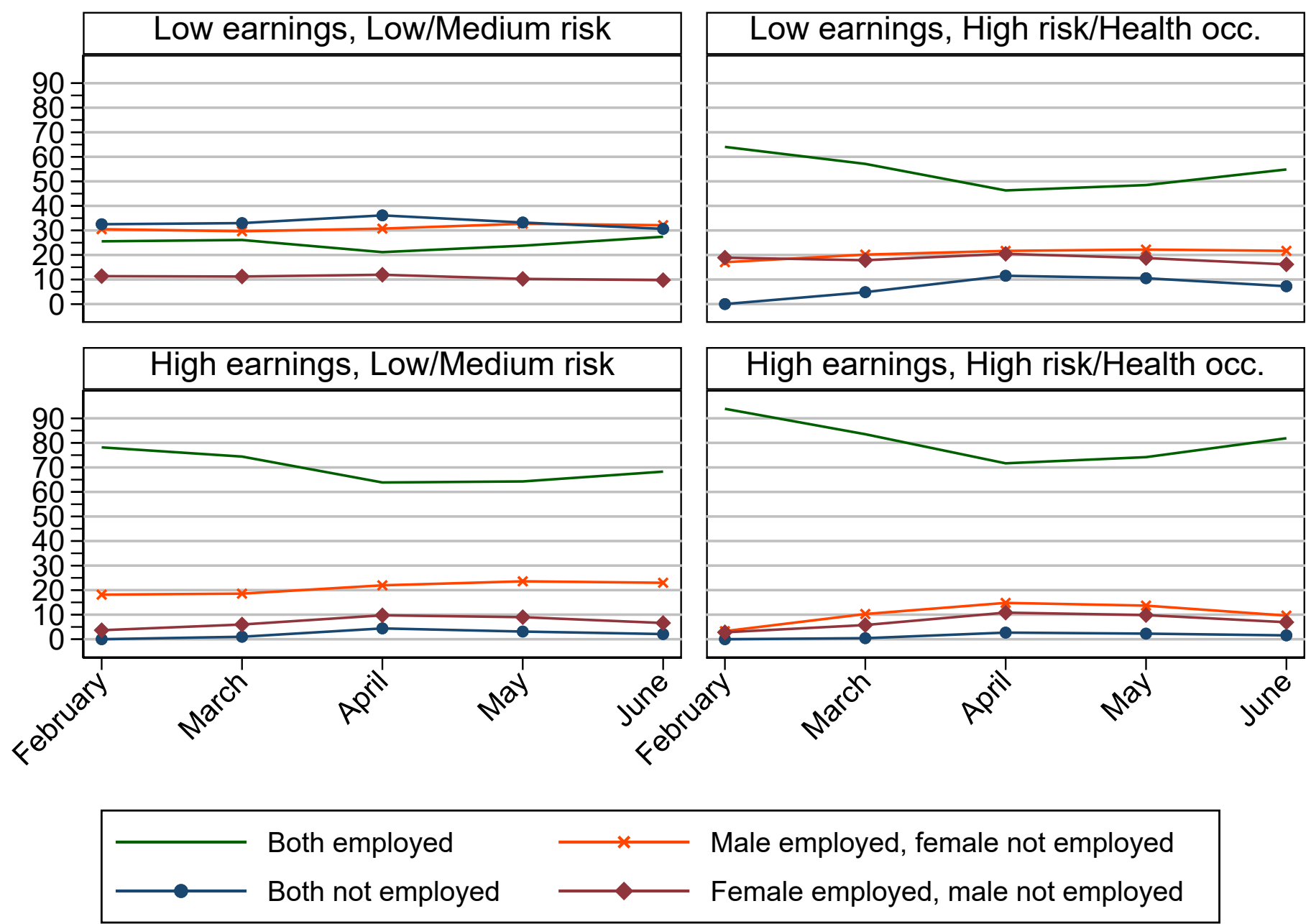

Notes: Sample restricted to the 2020 January and February rotations. Household earnings and individual risk index/occupation determined in February 2020.

\section{Conclusion}

The COVID pandemic has revealed the important inequalities that exist between workers in terms of their exposure to disease and to job loss, as well as the relationship that exists between the two forms of risk. In this paper, we characterize the distribution of both risks, and how they interact differently for women, low-educated workers, and recent immigrants.

At the onset of the pandemic, we worked closely with public health authorities in 
British Columbia and Québec to develop a risk index that could be used to plan the economic response to the crisis, the VSE Risk Index. The creation of this index constitutes our first contribution. While others before us have recognized the importance of job characteristics, input from public health officials and access to highly disaggregated data allowed us to incorporate worker characteristics into the measure and evaluation of risk. In this paper, we show that for certain groups, like immigrants, characterizing risk only in terms of at-work characteristics risk misses out an important dimension of viral risk. Furthermore, we find evidence that at-work risk components typically used until now may in part proxy for risk faced by workers through their living arrangements. This is an important policy consideration going forward, as much of the debate on viral containment has focused on the work place.

Our second contribution is to characterize how the viral and employment risk, as well as the relationship between the two, vary across various subgroups. We find that the VSE Risk Index is highly correlated with the proportion of women in an occupation, but bears no systematic relationship with other occupation-level worker characteristics, such as the prevalence of low-education workers in an occupation. Women also experienced important employment losses through the pandemic, contrasting with typical male-dominated employment losses in recent recessions. In comparison, low-educated workers and immigrants were hit most substantially by the "pandemic" recession, even though we find no evidence that occupations with higher proportions of either group were at greater risk of viral contagion.

While health occupations were among the riskiest in terms of viral contagion, the nature of the crisis was such that they experienced the smallest employment losses. Among non-health occupations however, we find a strong and positive relationship between viral risk and employment losses. At the peak of confinement, in April, high-risk occupations had lost $26.5 \%$ of employment, compared to less than $10 \%$ in low-risk occupations. Furthermore, while low-risk occupations had fully recovered by June, high-risk occupations were still $15.5 \%$ below the February employment levels. In great part, the net effect of the pandemic on employment, with respect to risk, can be explained by the fact that high-risk occupations were more likely to lose employment, but no more likely to regain employment after April. We show that the correlation between viral risk and employment loss was largely driven by occupations in which workers are required to perform job tasks in close physical proximity to others. However, this factor itself appears to proxy at least in part for economic disadvantage. Indeed, in regressions of occupation-level employment loss on at-work and at-home risk components, we find that controlling for the share of 
workers who live in crowded dwellings substantially reduces the size of the coefficient on proximity.

Thus, both types of risk that we examine - risk of exposure to the virus and risk of job loss - increased in ways that reflect deep-seated inequalities in Canadian society. Women have faced greater virus risk exposure because of the occupations in which they tend to work. That greater risk exposure combined with the fact that high risk occupations were more likely to lose employment completely explains the higher job loss for women, especially when measured relative to earlier recessions. Moreover, they had lower probabilities than men of being employed but absent from work, i.e., to maintaining a connection to the firm that turned out to improve workers' abilities to reconnect with employment during the recovery phase. They were also more likely than men to shift to working from home, which is likely reflects their making sacrifices related to work in order to care for children at home. At the same time, women did not face higher rates of layoff within occupations of a given risk type. That is, women were not more likely to be laid off simply because they were women.

In contrast, low educated workers did not face higher exposure to virus risk on the job but were much more likely to be laid off than high educated workers. This fits with observations in previous recessions that the low educated bear the brunt of job loss. We present a rough counterfactual exercise that implies that in the Covid recession, the extra job loss for the low educated can be accounted for by their lower propensity to switch to working from home and that lower propensity is due not to their job characteristics but to their home characteristics such as their greater tendency to work in crowded dwellings. In essence, long standing inequalities in living arrangements interacted with the virus to yield inequalities in job loss.

Taken together, our results reveal the ways in which the Covid crisis exposed the deep inequities in our society. Women faced more virus risk and were given less access to ongoing connections to the firm because of long standing occupational patterns and the division of work within the home. Low educated workers faced employment losses because their living arrangements made it less possible for them to adjust to the labour demand shock induced as a necessary response to Covid. The virus may affect us all but it moves through existing structures to increase inequality. 


\section{References}

Chernoff, A. W. and C. Warman (2020, July). COVID-19 and Implications for Automation. NBER Working Papers 27249, National Bureau of Economic Research, Inc.

Cortes, G. M. and E. Forsythe (2020, May). The heterogeneous labor market impacts of the COVID-19 pandemic. Working paper.

Dingel, J. I. and B. Neiman (2020). How many jobs can be done at home? Journal of Public Economics 189, 104235.

Gamio, L. (2020, March 15). The workers who face the greatest Coronavirus risk. The New York Times, https://nyti.ms/33j5mwB.

Jaimovich, N. and H. E. Siu (2020). Job polarization and jobless recoveries. Review of Economics and Statistics 102(1), 129-147.

Jones, S. R., F. Lange, W. C. Riddell, and C. Warman (2020). Waiting for recovery: The Canadian labour market in June 2020. Canadian Public Policy 46(S2), S102-S118.

Jones, S. R. and W. C. Riddell (2006). Unemployment and nonemployment: Heterogeneities in labor market states. Review of Economics and Statistics 88(2), 314-323.

Lemieux, T., K. Milligan, T. Schirle, and M. Skuterud (2020). Initial impacts of the COVID-19 pandemic on the Canadian labour market. Canadian Public Policy 46 (S1), S55-S65.

Mongey, S., L. Pilossoph, and A. Weinberg (2020, April). Which workers bear the burden of social distancing policies? BFI Working Paper No. 2020-51.

Mongey, S. and A. Weinberg (2020, March). Characteristics of workers in low work-fromhome and high personal-proximity occupations. BFI White Paper.

Montenovo, L., X. Jiang, F. L. Rojas, I. M. Schmutte, K. I. Simon, B. A. Weinberg, and C. Wing (2020, May). Determinants of disparities in Covid-19 job losses. NBER Working Paper No. 27132.

Vu, V. and N. Malli (2020, April 3). Anything but static: Risks of COVID-19 to workers in Canada. https://brookfieldinstitute.ca/p/7991. 